\title{
Amelioration of Some Physical Properties of Saline Sodic Soil in El-Tina Plain- North Sinai Area \\ Hoda A.Elia ${ }^{1}$
}

\begin{abstract}
The objective of this work was to investigate the influence of using each of rice straw (RS), agricultural gypsum requirements (AGR) and combination of them on improving soil physical and chemical properties. A sample of saline sodic, sandy clay loam soil, from the surface layer $(0-30 \mathrm{~cm})$ was taken from village 4 El-Tina plan, northern Sinai governorate - Egypt.

A greenhouse experiment was conducted, during winter of 2018/2019, three rates of $R S$ was used: $0.5,1$ and $1.5 \%$, also 6.8, 8.2, and 10.2 ton.fed ${ }^{-1}$ of AGR after calculating the AGR to reduce the ESP for the control sample to $50,60,75 \%$, respectively. In addition to combine of $0.5 \%$ RS + each of 6.8, 8.2 and 10.2 ton.fed ${ }^{-1}$ AGR, each treatment was mixed with soil $30 \mathrm{~cm}$ depth in pots. The soil was incubated for one month before cultivation, with Spinach (Spinacia Oleracea, L), in $1^{\text {st }}$ December, 2018 as a guide crop. The amount of irrigation water was determined by weighting each pot to keep the moisture content at the field capacity of each treatment plus $15 \%$ as a leaching requirement of applied water.

The obtained results indicated that, the adding (RS) or / and (AGR) led to increase the soil's ability to retain soil moisture content, porosity, water holding pore and H.C. Meanwhile, decreases soil bulk density, penetration resistance (PR), EC, ESP and pH in compared to control. The superior effect on improvement of these parameters was resulted in combine RS+AGR. Also effect of the treatments on these properties in $0-10 \mathrm{~cm}$ soil depth $>10$ $20>20-30 \mathrm{~cm}$ soil depth. The results revealed that the values of field capacity (FC), available water (AW), H.C, quickly drainable pores (QDP) and water holding pore (WHP) increased significantly by increasing the rate of RS and GR. Moreover, combine RS + each of 6.8, 8.2 and 10.2 ton.fed $^{-1}$ AGR was increased highly significant effect on, FC, AW, H.C, QDP and WHP as compared to treated by RS, AGR alone or control. Also, it was decreased significantly on PR, bulk density and fine capillary pore. ESP values decrease by leaching control was not considerable and the soil remained sodic with highly ESP values. However, the final ESP obtained after leaching with amendments gave the highest decrease percent in ESP values by using combine $0.5 \% \mathrm{RS}+$ each of $6.8,8.2$ and 10.2 ton. fed ${ }^{-1}$ AGR. Also, the fresh yield of Spinach was higher in soils receiving with increasing rates of $A G$ amendment as compared to RS. The highest shoot spinach yield was, obtained by treatment by combine of $0.5 \% \mathrm{RS}+$ each of 6.8, 8.2 and 10.2 ton. fed ${ }^{-1}$ AGR.
\end{abstract}

DOI: 10.21608/ASEJAIQJSAE.2019.52643

${ }^{1}$ Desert Research center, Mattariya, Cairo, Egypt.

Received August 28, 2019, Accepted September 30, 2019
Key words: Saline sodic soils, agricultural gypsum, soil physical and chemical properties, reclamation, rice straw compost.

\section{INTRODUCTION}

In Egypt, as in many other countries in arid and semi-arid areas, soil salinity and sodicity very often occur and transferred due to climate conditions of weakened rainfall and rising temperatures, lead to upward flux and salt accumulation on soil surface as well as the salts in irrigation water and capillary rise of saline water table cause the increase of soil salinity. The area of salt-affected soils are approximately 2 million fed of cultivation is 7.5 million fed. Soil amendments are corporate into upper layer of soil $(\mathrm{cm})$ to ameliorate soil physical properties; like water retention, water infiltration, permeability and supply nutrients.

There were many ways to allow water and nutrients to flow easier through the soil to boost healthy plant growth Ammari et al, (2008). There are two types of soil amendments: $1^{\text {st }}$ one, organic amendments which include straw, wood chips, sphagnum peat, manure, compost, biosolids, wood ash, and sawdust....ect, which enhance water stabile aggregate, infiltration rate and water-holding capacity Diacono, and Montemurro, (2015). the $2^{\text {nd }}$ one, Inorganic amendments like, vermiculite, perlite, and sand,....ect, which applied to improvement and reclamation saline soil to avoid the using chemical amendments on soil and decrease salts concentration in the upper layer of soil, which enhanced the plants growth by get rid the excessive ions released from soil to the deeper layers. Junbao et al., (2010). Agricultural gypsum, sulphur, acids, press mud and farmyard manure (FYM) are used to reclaim the salinesodic soils. Sabir et al.,(2007) and Bello, (2012).

In Egypt, agricultural gypsum is usually used to reclaim sodic soils due to it is easily of handling, low cost and availability. Gypsum decreases the ratio of sodicity to salinity in percolating solutions and provides constant hydraulic gradient throughout the soil profile. The gypsum application followed by a mature municipal solid compost mix has been used to restore degraded sodic soils Hanay et al., (2004). Gypsum treatment was effective in the sodic soils reclamation. In addition, decreases of, electrical conductivity, exchangeable sodium percentage and $\mathrm{pH}$, Gupta et al., 
(1988), decrease the bulk density values and inversely, increases soil infiltration rate and soil hydraulic conductivity Abdel-Fattah, (2012); Abou Youssef, (2001) found that, with increasing application of phosphor gypsum (PG) decreased values of bulk density, $\mathrm{pH}, \mathrm{EC}$ values and ESP. In the other hand, there were increase soil hydraulic conductivity, soil porosity, mean weight diameter (MWD) of soil aggregates, geometric mean diameter (GMD), and water-stable aggregates (WSA). Manzoor et al., (2001) mentioned that the sodium adsorption ratio (SAR), electrical conductivity (EC) and soil $\mathrm{pH}$ decreased with gypsum application. Many studies El-Shanawany (1985); Lebron and Yoshida (2002) indicated that gypsum and phospho-gypsum improved the soil structure, decreased the swelling of sodic soils, increased soil hydraulic conductivity $(\mathrm{Ks} / \mathrm{Kh})$ and infiltration rate.

Chawla and Abrol (1982) reported that treatments with the finest gypsum resulted in the greatest initial infiltration rate, then sharply decrease with time. This phenomenon was due to the greater solubility of the finer particles followed by a decrease sharply in the electrolyte concentration due to the precipitation of dissolved calcium in the first case and the dissolution of coarser particles and little precipitation in the final case. The inactivation of gypsum particles due to formation of calcium carbonate $\left(\mathrm{CaCO}_{3}\right)$ coatings over their surfaces reported in the case of finer grades. Whereas the kinetics of gypsum dissolution in the presence of soil is first order while the absence of soil is second order. This vary in reaction kinetics resulted from the continuous removal of calcium ion $\left(\mathrm{Ca}^{2+}\right)$ and sulfate ions $\left(\mathrm{SO}_{4}{ }^{2+}\right)$ from the soil.

Laboratory experiments conducted by Vandenelshout and Kamphorst (1990) to evaluate the water requirements for leaching for five gypsum grades with different particle size distributions reveal that the water requirements for leaching didn't difference significantly for the mixtures studied, provided that the percolation rates were low. The time of reclamation appeared to increase with increasing particle size. Different methods of gypsum application were tested The largest efficiency can be obtained when partially mixing and applying an equal amount to the gypsum requirement into the soil. Based on the lack of comparative information for the situation in Egypt.

The main objective of this work was to study the applying gypsum and rice straw individually or their combination on improvement of physical and chemical characteristic of a saline sodic in El Tain -plain. in Egypt.

\section{MATERIALS AND METHODS}

The experiment was conducted to elucidate the effect of the application Rice straw, Agricultural gypsum (particles 1-2 mm) and their combinations on some soil physical and chemical properties and productivity of saline sodic, sandy clay loam soil was studied. Soil sample was collected from the surface layer $(0-30 \mathrm{~cm})$ in village 4, El-Tina plain, east of the Suez Canal in North Sinai Governorate. Three rates: $0.5,1$ and $1.5 \%$ of rice straw pieces ( $2 \mathrm{~cm}$ length), three application rates of agricultural gypsum requirements (AGR) 50, 60 and $75 \%$ which were 6.8, 8.2 and 10.2 ton.fed ${ }^{-1}$ agricultural gypsum, respectively, and combine of $0.5 \%$ rice straw each of $6.8,8.2$ and 10.2 ton.fed $^{-1}$ agricultural gypsum were used. Soil treatments were mixed with soil $(30 \mathrm{~cm}$ depth). These soil treatments were incubated for one month before cultivation of Spinach in greenhouse pots experimental. Cultivated with spinach (Spinacia Oleracea, L) was planted in $1^{\text {st }}$ December, 2018- 2019 as a guide crop. This experiment was irrigated by water from the El-Salam Canal with a 1:1 mixture of agriculture drainage water and fresh Nile water and a representative soil sample was taken before planting to determine some physical and chemical properties Table(1).

1-Agricultural gypsum requirements (AGR) were determined according to the methods described by U.S., salinity laboratory staff (FAO and IIASA, 2000).

2- Calculated as follows:

$$
\text { AGR }=\frac{\text { ESPi-ESPf }}{100} x \text { CEC } x 1.72 x \text { gypsum purity. }
$$

Where AGR: agricultural gypsum requirement (ton.fed $\left.{ }^{-1}\right)$ CEC: cation exchange capacity (meq. $100 \mathrm{~g}^{-1}$ soil), ESP $\mathrm{E}_{\mathrm{i}}$ is initial the Exchangeable Sodium in the soil (measured), $\mathrm{ESP}_{\mathrm{f}}$ is the Exchangeable Sodium Percentage to be reached (descending the previous measured).

3-Exchangeable sodium percentage (ESP) was estimated by using the following equation:

$$
\mathrm{ESP}=\frac{100(-0.0126+0.01475 \mathrm{SAR})}{1+(-0.0126+0.01475 \mathrm{SAR})}
$$

4- Sodium adsorption ratio (SAR) was estimated by using the following equation where ionic concentration of the saturation extracts are expressed in meq. $\mathrm{L}^{-1}$

$$
\mathrm{SAR}=\frac{\mathrm{Na}}{\sqrt{\mathrm{Ca}+\mathrm{Mg} / 2}}
$$

Soil sample was analyzed to review the amount of gypsum, as well as different percentages of cutting rice straw with soil $(0,0.5,1.0$, and $1.5 \%)$. 
Table 1. The main values of some physical and chemical soil properties of the (virginal) control soil under study and of irrigation water

\begin{tabular}{lcccc}
\hline & \multicolumn{2}{c}{ Soil } & Irrig. water \\
\hline Coarse sand \% & 11.18 & $\mathrm{EC} \mathrm{dSm}^{-1}$ in soil paste & 19.6 & 2.19 \\
Fine sand \% & 49.45 & $\mathrm{pH} \mathrm{in} \mathrm{soil} \mathrm{paste}$ & 8.2 & 7.92 \\
Silt \% & 11.24 & $\mathrm{Ca}^{++}\left(\mathrm{meq} \mathrm{L}^{-1}\right)$ & 15.2 & 2.34 \\
Clay \% & 28.13 & $\mathrm{Mg}^{++}\left(\mathrm{meq} \mathrm{L}^{-1}\right)$ & 19.9 & 3.94 \\
Textural class & $\mathrm{SCL}$. & $\mathrm{Na}^{+}\left(\mathrm{meq} \mathrm{L}^{-1}\right)$ & 156.0 & 15.19 \\
Bulk density ton. ${ }^{-3}$ & 1.51 & $\mathrm{~K}^{+}\left(\mathrm{meq} \mathrm{L}^{-1}\right)$ & 4.9 & 0.42 \\
Total porosity \% & 43.0 & $\mathrm{HCO}^{--}\left(\mathrm{meq} \mathrm{L}^{-1}\right)$ & 12.8 & 3.99 \\
$\mathrm{Ca} \mathrm{CO}_{3}$ (g/Kg) & 0.41 & $\mathrm{Cl}^{-1}\left(\mathrm{meq} \mathrm{L}^{-1}\right)$ & 121.1 & 12.39 \\
Organic matter \% & $\mathrm{SO}--\left(\mathrm{meq} \mathrm{L}^{-1}\right)$ & 62.1 & 5.51 \\
Field capacity \% & $\mathrm{SAR}$ & 37.3 & 8.57 \\
Welting point \% & 0.34 & $\mathrm{CEC} \mathrm{meq/100} \mathrm{gm} \mathrm{soil}$ & 21.6 & ---- \\
Available water \% & 21.1 & $\mathrm{ESP} \%$ & 34.9 & --- \\
Hydraulic conductivity $\mathrm{cm} \mathrm{h}^{-1}$ & 11.6 & & \\
\hline
\end{tabular}

Also, agricultural gypsum requirements (AGR) were calculated to reduce the initial ESP $=35 \%$ to ESP $=17.5,14$ and $9 \%$ for $30-\mathrm{cm}$ soil depth, according to U.S. salinity laboratory staff FAO and IIASA, (2000), and combination of $0.5 \%$ rice straw + each of $6.8,8.2$ and 10.2 ton.fed $^{-1}$ agricultural gypsum, which were 50 , 60 and $75 \%$ agricultural gypsum requirements (AGR).

The amount of irrigation water was determined by weighting each pot to keep the moisture content at the field capacity of each treatment, with the addition to $15 \%$ as leaching requirement.

In the end, experiment soil samples were taken from each pots at $0-10,10-20$ and $20-30 \mathrm{~cm}$ soil depth in order to determine Soil physical properties are: Field capacity, wilting point, available water, hydraulic conductivity (Darcy's law), bulk density, total porosity and pore size distribution of the soil. Pore size distribution was determined according to the equation:

$\mathrm{P}=(2 \sigma \operatorname{COS} \theta) / \mathrm{r}$ Where $\mathrm{r}$ is pore radius, $\sigma$ is surface tension of water $(\sigma=72$ dyne $/ \mathrm{cm}), \theta$ is the contact angle and $\mathrm{P}$ is the applied pressure. When contact angle equals Zero, the pore diameter corresponds to pressure $0.01,0.033$ and $1.5 \mathrm{MPa}$ is equal to $28.8,8.62$ and 0.19 micron, respectively. according to De Leenher and De Boodt (1965) classified the pore space to pore with a diameter $>28.8 \mu$ as quick drainable pores, while those with diameters $28.8-8.62 \mu$ as slow drainable pores and water holding pores as the pores with diameters 8.62- 0.19 micron.

soil physical properties analysis according to klute (1986). Soil penetration resistance was measured in the vicinity, each of the representative soil pots using an electrical penetrometer. Statistical analysis of variance of all treatments were compared in a complete randomize plot design using ANOVA and the least significant difference (L.S.D) at $0.05 \%$ level.

\section{RESULTS AND DISCUSSION}

\section{Soil physical properties:}

\section{Soil moisture characteristics:-}

Data in Table (2), indicates that adding any of rice straw (RS) or agricultural gypsum requirements (AGR) at any rate increase the retained moisture in soil at any suction. Also increasing in the percentages of retained moisture at all suctions, this increase of field capacity and available water values was higher with increasing the applied rate of rice straw (RS) or agricultural gypsum (AGR.) compare to control. Moreover, combination of RS + AGR treatments were superior in increasing FC and AW values as compared to RS, AGR or control. Data in Table (2) showed that, the 0-10 soil depth, values of retained moisture at field capacity (FC) increased with increasing rates of 5.7, 11.1 and $17.4 \%$ by application of $0.5,1$ and $1.5 \%$ rice straw. In addition, the increasing rates of retained moisture values at (FC) were $12.2,15.8$ and $13.6 \%$ for application $6.8,8.2$ and 10.2 ton.fed $^{-1}$ agricultural gypsum requirements. In addition, the increasing rates of water content at field capacity values were $15.9,17.3$ and $26.5 \%$ for combined $0.5 \%$ rice straw + each of $6.8,8.2$ and 10.2 ton.fed ${ }^{-1}$ agricultural gypsum respectively, as compared with control.

Data in table (2) revealed that increasing rates of the available water values were $12.5,23.4$ and $31.9 \%$ by application of $0.5,1$ and $1.5 \%$ RS. In addition, the increasing rates of available water values were 23.4 , 31.2 and $28 \%$ for application $6.8,8.2$ and 10.2 ton.fed- ${ }^{1}$ AGR. While the increasing rates of available water values were $34,35.5$ and $50.6 \%$ for combine $0.5 \%$ R. S 
+ each of 6.8, 8.2 and 10.2 ton.fed $^{-1}$ AGR respectively, as compared with control treatment.

The positive effect of RS, AGR and their combination application in increasing available water reflects the high capacity and available water content of these amendments in retaining more moisture in the soil through creating more water holding pores in the soil in particular as well as increasing soil porosity in general. Moreover, the combination of RS + each of 6.8, 8.2 and 10.2 ton.fed $^{-1} \mathrm{AG}$, were ability to retaining more moisture in the soil higher than RS or AGR alone. Whereas the increasing values of field capacity 10-20 cm soil depth 19.1, $13 \& 16.4 \%$, of treated by RS, also it was 10,13 and $13.1 \%$ of treated by AGR and 15.2, 19.3 and $22.2 \%$ of combine $0.5 \%$ RS + each of $6.8,8.2$ and 10.2 ton.fed $^{-1} \mathrm{AG}$. In addition soil depth $10-20 \mathrm{~cm}$, the values increasing of available water was $(39.5,31.7$ $\& 42.6 \%),(38.8,33.1 \& 51.8 \%)$ and $(57.3,43.6 \&$ $48.9 \%)$. Also, of $20-30 \mathrm{~cm}$ soil depth, it was $(32.2,31.6$ $\& 23.7 \%),(35.8,34.3 \& 37.9 \%)$ and $(35.2,49.7$ and $55.4 \%$ ) respectively compare to control.

Data presented in Table $\left(6_{\mathrm{a}}, 6_{\mathrm{b}}\right.$, and $\left.6_{\mathrm{c}}\right)$ indicated that addition of rice straw, agricultural gypsum increased significantly affected in Field capacity (FC) and available water (AW) as compared to soil without any conditioners (control). Also, results revealed that the values of FC and AW increased significantly by increasing the rate of rice straw and agricultural gypsum conditioners, in three soil depths. These results are similar to those obtained by (Sharma and Minhas, 2005) who found that compost significantly increased soil water content. Also, these results may be due to gypsum plays a significant role in the providing a $\mathrm{Ca}^{2+}$ cation to replace the exchangeable $\mathrm{Na}^{+}$on the exchange positions and leaching it and removing down root zone. Sharma et al (1995) reveal that the aggregation stability was improved sodic soil by gypsum application. Also increasing water stable aggregates in both $0-10$ and 1020 and 20-30 soil depth. These increases considers with increases in total porosity. These results are in accordance with those obtained by Ghazy (1994) who reported that available soil moisture was increased with application of agricultural gypsum. Also this is due to the increasing of the decomposition rate of organic matter by time and the indirect effect of organic matter on soil physical and chemical properties.

\section{Soil bulk density:}

Table (2) and Fig. (1) Revealed that application of (RS) or (AGR) individual and their combination had a marked effect high relatively on bulk density of the saline sodic soil. Bulk density was decrease with increasing rates added of RS, AGR and their combination of them of soil. Data of $0-10 \mathrm{~cm}$ soil depth, the application rates $0.5,1$ and $1.5 \%$ RS lead to, soil BD values decreased by $1.41,1.36$ and $1.32 \mathrm{gm} . \mathrm{cm}^{-3}$, by reduction of $6.6,9.9$ and $12.6 \%$ compare to control $\left(\mathrm{BD}_{0}\right)$. In addition, $\mathrm{BD}$ values decreased to $1.4,1.36$ and $1.31 \mathrm{gm} . \mathrm{cm}^{-3}$ by the application of $6.8,8.2$ and 10.2 ton.fed $^{-1}$ AGR, with reduction of $7.3,9.9$ and $13.3 \%$. meanwhile, data referred that soil BD decreased to 1.30, 1.26 and 1.23 gm. $\mathrm{cm}^{-3}$ by application of combination $0.5 \% \mathrm{RS}+$ each of 6.8, 8.2 and 10.2 ton.fed ${ }^{-1}$ AGR by reduction of 13.9, 16.6 and $18.5 \%$ as compared to control $\left(1.51 \mathrm{gm} . \mathrm{cm}^{-3}\right)$, respectively. These results are in accordance with those reported by Wong and Ho (1991) who attributed the decrease in soil bulk density to the effect of gypsum or /and organic matter increasing the stability of aggregates. Also decreasing soil bulk density of application by agricultural gypsum is mainly attribute to the effect of agricultural gypsum on improving the physical properties of soil via increasing total pore space. Also, data show that the decrease of soil bulk by $12.6 \%, 13.3 \%$ was obtained with added individual 1.5 $\%$ of rice straw or 10.2 ton.fed $^{-1} \mathrm{AG}$, respectively. While the highest decrease of bulk density $(18.5 \%)$ of combine $0.5 \%$ rice straw +10.2 ton.fed $^{-1}$ AG. The average values of bulk density for $0-10,10-20$ and 20 $30 \mathrm{~cm}$ soil layers were decreased by $(9.7 \%, 10.2$ and $16.3 \%),(7.2,9.2$ and $14.8 \%)$ and (7.5, 9.2 and $14.5 \%)$ for RS, AGR and combination of RS + AGR applications respectively, compared to control. Also, data illustrated in Table (2) and Fig. (1) indicate that the addition of RS or AGR and combination of them, with successive leaching (irrigation) caused a pronounced decrease in saline soil, this lead to decrease the value of soil bulk density in both the surface and subsurface soil depths. This effect was more pronounced in $0-10 \mathrm{~cm}$ than 10-20 and $20-30 \mathrm{~cm}$ soil depth, The highest value decrease of soil bulk density occurred with application of $0.5 \% \mathrm{RS}+10.2$ ton.fed $^{-1} \mathrm{AG}$, the values were 1.23 , 12.8 and $1.31 \mathrm{gm} / \mathrm{c} \mathrm{m}^{3}$, respectively. These results are in agreement with those found by El- Shanawany (1985) and Wahby(1986) who found that increasing the rates of applied gypsum and leaching water gave the lowest values of soil bulk density.

The role of compost may be related to increase of soil granulation, increase porosity, decrease soil density and improving soil properties, Antar, et al 2008. However, the decrease in soil bulk density of combine $0.5 \%$ rice straw +10.2 ton. fed $^{-1} \mathrm{AG}$ application, in soil exceed $18.54 \%$ in the surface layer, this finding illustrates marked the role of rice straw + agricultural gypsum in highest improve soil bulk density. Application different rates of soil amendments a descending decrease in the order as follows 
Table 2. Effect of different rates of rice straw, gypsum and their combination amendments on some physical properties soil in EI Tina plain

\begin{tabular}{|c|c|c|c|c|c|c|c|c|c|c|c|c|c|c|}
\hline \multirow{2}{*}{\multicolumn{2}{|c|}{ Treatments }} & \multirow{2}{*}{ 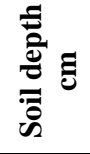 } & \multicolumn{8}{|c|}{ Retained soil moisture at the indicated tension, (MPa) } & \multirow{2}{*}{$\frac{8}{4}$} & \multirow{2}{*}{ 岂 } & \multirow{2}{*}{ คُ } & \multirow{2}{*}{ 穿 } \\
\hline & & & 0.00 & 006 & 0.01 & .033 & 0.1 & 0.3 & 0.5 & 1.5 & & & & \\
\hline \multirow{9}{*}{$\underbrace{2}_{\tilde{a}}$} & \multirow{3}{*}{$\begin{array}{l}0 \\
n \\
0\end{array}$} & $0: 10$ & 43.71 & (6) & 32.26 & 50.01 & 20.00 & 27.66 & 20.14 & 12.26 & 18.55 & 1.36 & 1.41 & 46.79 \\
\hline & & $10: 20$ & 46.71 & 36.28 & 31.13 & 29.84 & 25.57 & 23.65 & 22.96 & 12.41 & 17.43 & 0.91 & 1.45 & 45.28 \\
\hline & & $20: 30$ & 43.44 & 34.83 & 28.88 & 24.77 & 26.25 & 24.05 & 25.59 & 12.52 & 12.25 & 0.96 & 1.48 & 44.15 \\
\hline & \multirow{3}{*}{ 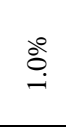 } & $0: 10$ & 46.73 & 36.83 & 34.11 & 32.37 & 31.17 & 29.78 & 28.58 & 12.03 & 20.34 & 1.67 & 1.36 & 48.68 \\
\hline & & $10: 20$ & 47.53 & 38.79 & 30.57 & 28.31 & 26.87 & 25.87 & 24.72 & 11.86 & 16.45 & 1.58 & 1.43 & 46.04 \\
\hline & & $20: 30$ & 44.20 & 37.24 & 29.32 & 23.50 & 27.00 & 26.54 & 22.58 & 11.30 & 12.20 & 1.04 & 1.44 & 45.66 \\
\hline & \multirow{3}{*}{$\stackrel{\circ}{n}$} & $0: 10$ & 49.08 & 39.14 & 35.16 & $J$ & 28.10 & 27.72 & 25.53 & 12.49 & 21.74 & 1.83 & 1.32 & 50.19 \\
\hline & & $10: 20$ & 49.18 & 40.74 & 30.48 & 29.18 & 28.41 & 23.32 & 23.00 & 11.37 & 17.81 & 1.47 & 1.38 & 47.92 \\
\hline & & $20: 30$ & 45.74 & 39.11 & 29.23 & 24.22 & 27.34 & 26.69 & 24.78 & 12.75 & 11.47 & 1.18 & 1.41 & 46.79 \\
\hline \multirow{9}{*}{ 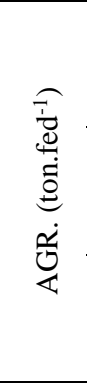 } & \multirow{3}{*}{$\stackrel{\infty}{\infty}$} & $0: 10$ & 45.43 & 35.24 & 3. & 32 & 27.36 & 27.09 & 25.19 & 2.35 & 20.34 & 1.41 & 1.4 & 47.17 \\
\hline & & $10: 20$ & 46.78 & 37.71 & 29.25 & 27.55 & 27.13 & 22.71 & 22.48 & 11.92 & 17.33 & 1.31 & 1.42 & 46.42 \\
\hline & & $20: 30$ & 43.50 & 37.71 & 28.00 & 22.87 & 22.40 & 21 & 20.79 & 10.28 & 59 & 0.87 & 1.45 & 45.28 \\
\hline & \multirow{3}{*}{$\stackrel{\infty}{\infty}$} & $0: 10$ & 47.06 & 3 & 3 & 6 & 30 & 26 & 23.39 & 14 & 62 & 1.91 & 1.36 & 48.68 \\
\hline & & $10: 20$ & 47.06 & 6 & 28 & 2 & 02 & 23.49 & 22.25 & 86 & 62 & 1.54 & 1.39 & 47.55 \\
\hline & & $20: 30$ & 43.76 & 39.06 & 27. & 23. & 23.56 & 24.34 & 22.02 & 11.07 & 12.45 & 0.97 & 1.42 & 46.42 \\
\hline & \multirow{3}{*}{$\stackrel{2}{0}$} & $0: 10$ & 48.84 & 3 & 3 & 2 & 72 & 2 & 2 & 1 & 08 & 2.06 & 1.31 & 50.57 \\
\hline & & $10: 20$ & 48 & 4 & 2 & 2 & 9 & 2 & 2 & 9 & 95 & 1.86 & 1.36 & 48.68 \\
\hline & & $20: 30$ & 4 & 1 & 2 & 3 & 1 & 2 & 7 & 74 & 79 & 1.46 & 1.38 & 47.92 \\
\hline \multirow{9}{*}{ 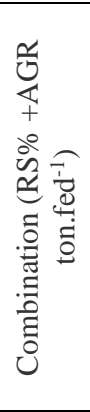 } & \multirow{3}{*}{ 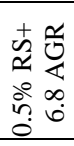 } & $0: 10$ & 51.64 & - & 9 & & 36 & 27.59 & 24.89 & 11.70 & 22.09 & 2.12 & 1.3 & 50.94 \\
\hline & & $10: 20$ & 51.64 & 42.86 & 31.38 & 28.87 & 28.05 & 24.37 & 22.90 & 11.74 & 19.64 & 1.59 & 1.33 & 49.81 \\
\hline & & $20: 30$ & 48.03 & 41.15 & 30.13 & 23.97 & 24.37 & 23.60 & 22.92 & 11.43 & 12.53 & 1.22 & 1.36 & 48.68 \\
\hline & \multirow{3}{*}{ 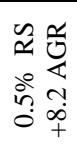 } & $0: 10$ & 53.13 & 36.98 & 35.82 & 34.20 & 26.89 & 25.52 & 25.90 & 11.88 & 22.32 & 2.62 & 1.26 & 52.45 \\
\hline & & $10: 20$ & 53.13 & 44.10 & 30.69 & 29.90 & 28.39 & 22.32 & 21.18 & 11.96 & 17.93 & 1.70 & 1.3 & 50.94 \\
\hline & & $20: 30$ & 49.41 & 42.34 & 29.44 & 24.81 & 23.71 & 22.71 & 22.17 & 10.94 & 13.87 & 1.54 & 1.33 & 49.81 \\
\hline & \multirow{3}{*}{$\begin{array}{ll}2 & 0 \\
0 & \mathbb{4} \\
0 & 0 \\
\vdots & 0 \\
0 & +\end{array}$} & $0: 10$ & 55.58 & 37.13 & 37.89 & 36.86 & 28.17 & 26.35 & 25.46 & 12.04 & 24.82 & 2.88 & 1.23 & 53.58 \\
\hline & & $10: 20$ & 56.58 & 46.96 & 30.82 & 30.62 & 28.11 & 23.38 & 21.87 & 12.02 & 18.60 & 1.89 & 1.28 & 51.70 \\
\hline & & $20: 30$ & 52.62 & 45.08 & 29.57 & 25.41 & 24.86 & 23.38 & 24.64 & 11.01 & 14.40 & 1.54 & 1.31 & 50.57 \\
\hline \multirow{3}{*}{\multicolumn{2}{|c|}{ Control }} & $0: 10$ & 41.62 & 33.41 & 31.40 & 29.15 & 24.89 & 24.67 & 23.15 & 12.67 & 16.48 & 0.84 & 1.51 & 43.02 \\
\hline & & $10: 20$ & 43.63 & 36.54 & 28.73 & 25.06 & 26.20 & 22.66 & 22.48 & 12.56 & 12.50 & 0.75 & 1.53 & 42.26 \\
\hline & & $20: 30$ & 40.58 & 35.08 & 27.48 & 20.80 & 21.64 & 21.32 & 19.80 & 11.54 & 9.26 & 0.54 & 1.56 & 41.13 \\
\hline
\end{tabular}

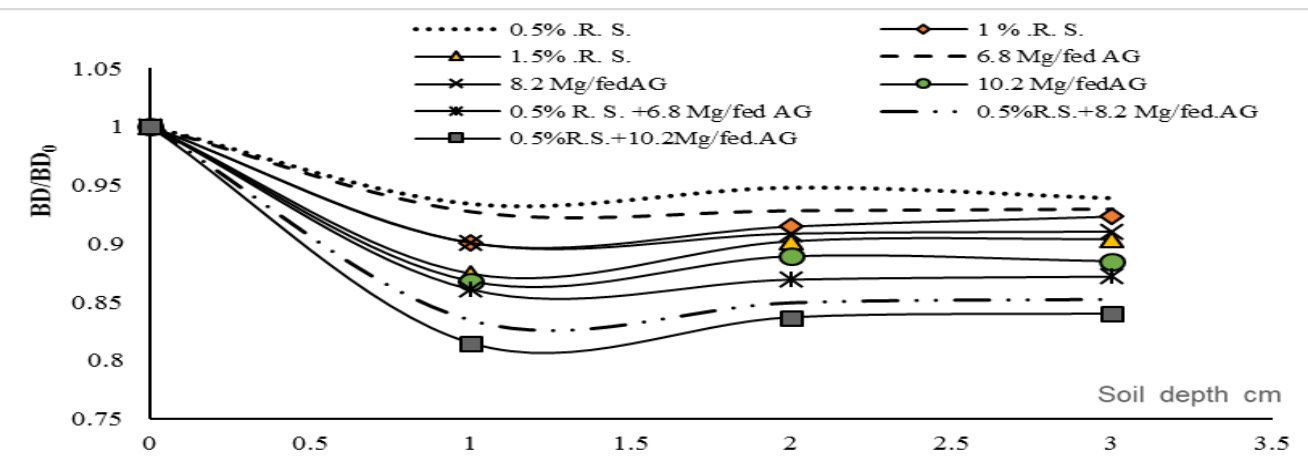

Fig. 1. Changes of BD rates under different treatments by RS, AG and their combination in 0-10, 10-20 and 20$30 \mathrm{~cm}$ soil layers 
$0.5 \%$ RS +10.2 ton.fed ${ }^{-1}$ AG $>0.5 \%$ RS +8.2 ton.fed $^{-1}$ $\mathrm{AG}>0.5 \% \mathrm{RS}+6.8$ ton.fed $^{-1} \mathrm{AG}>10.2$ ton.fed $^{-1} \mathrm{AG}>$ 8.2 ton.fed $^{-1} \mathrm{AG}>6.8$ ton.fed $^{-1} \mathrm{AG}>1.5 \% \mathrm{RS}>1 \%$ $\mathrm{RS}>0.5 \% \mathrm{RS}$. This trend is hold true for $0-10,10-20$ and 20-30 cm soil depth layers, respectively.

Statistical analysis in table $\left(6_{\mathrm{a}}, 6_{\mathrm{b}}\right.$, and $\left.6_{\mathrm{c}}\right)$ indicated that there are significant differences among the different treatments of amendments, also in three soil depth.

\section{Total porosity:}

Data in Table (2) indicated that the total soil porosity increased due to increasing addition of RS, AGR and their combination. This increase was more noticeable in the $0-10 \mathrm{~cm}$ than the $10-20$ and $20-30 \mathrm{~cm}$ soil depth. The highest relative increases in soil porosity in $0-10$ $\mathrm{cm}$ soil depth were $16.7 \%, 17.5 \%$ and $24.6 \%$ by $1.5 \%$ RS, 10.2 ton.fed ${ }^{-1}$ AGR and combine $0.5 \%$ RS +10.2 ton.fed $^{-1}$ AG respectively. The corresponding values of decreases in the 10-20 and $20-30 \mathrm{~cm}$ soil depth were $13.4,15.2 \& 22.3 \%$ and $13.8,16.5 \& 22.9 \%$ for the same application treatments, respective. Similar results were obtained by Wahby (1986) found that the total soil porosity reached highest values by agricultural gypsum was added to saline sodic soil.

Data in Table (2) also, showed that values of the total porosity were higher in the surface layers than in the subsurface others, where total porosity values of control were $43 \%, 42.3 \%$ and $41.1 \%$ in $0-10,10-20$ and $20-30 \mathrm{~cm}$ soil depths. Also, total porosity increased with increasing agricultural gypsum treated. Where porosity values were $47.2,48.7$ and $50.6 \%$ in $0-10$ soil depth, (46.4, 47.6 and 48.7) and (45.3, 46.4 and $47.9 \%)$ for the others soil depths. On the other hand, the total porosity for $0.5,1$ and $1.5 \%$ Rice Straw was $46.79,48.68$ and $50.19 \%$ in the surface layers, respectively. Meanwhile, the highest value was $53.6 \%$ by combine $0.5 \% \mathrm{RS}+$ 10.2 ton.fed $^{-1}$ AGR. This indicates that the combination $0.5 \%$ RS+ AGR in soil were more efficient in increasing total porosity, probably due to the continuous supply of $\mathrm{Ca}^{+2}$ and $\mathrm{RS}$ as a source of organic matter in soil which enhances the aggregation process. These results are in good agreement with that obtained by El- Shanawany (1985) who reported that applied gypsum particularly or /and organic matter in high rates gave the highest values of total soil porosity. Also, these results may be attributed to the role of soil amendments in increasing exchangeable calcium which enhance the aggregation process and consequently increase apparent soil bulk volume, decrease soil bulk density and increase the efficiency of leaching processes with adding amendments. The obtained results are similar to those reported by Abd El-Hamid et al. 2011.

\section{Soil hydraulic conductivity (H.C.):}

Data in Table (2) showed that the values of hydraulic conductivity in initial soil were decreased as a result of increasing soil salinity and alkalinity which, decreases the volume of drainable pores. This behavior may be due to the dispersion of soil particles created by sodium ions that occupy a pronounced area of the exchangeable sites. Also, it might be attributed to the internal swelling that would narrow the pores and allow for more entrapment of slaked and dispersed particles; internal swelling reduces the number of large free drainable pores, which are responsible for saturated water movement. Data also showed the effect of different rates of RS or AGR amendments and their combination on soil hydraulic conductivity, the data revealed that the leaching processes did help in increasing the hydraulic conductivity values compared to control soil. Also, the increasing hydraulic conductivity values was maximized of combined rice straw + agricultural gypsum treatment in soil under study. The increasing rates of amendments RS or AGR lead to increased H.C. values and the numerical values were higher than (control soil $\mathrm{HC}_{0}$ ), but lower than the H.C. values, by application combination of $0.5 \%$ RS with each of $6.8,8.2$ and 10.2 ton.fed $^{-1}$ of AGR. As regard the reclamation efficiency in terms of improving hydraulic conductivity, various amendments proved useful but the combination of $0.5 \%$ rice straw with combine different rates of agricultural gypsum may be regarded the best. This finding is agreement with Hussain et al., (2001) who found that application of amendment in lesser quantities in combination may be a good strategy to reclaim the sodic soils.

Data in Table (2) and Fig (2) also showed the values of hydraulic conductivity (H.C.) are response to the application of different soil amendments. Also the data in Table $\left(6_{a}, 6_{b}\right.$, and $\left.6_{c}\right)$ showed that the values of (H.C.) were significantly increased under application of all amendments. The superiority of the treatment of 0.5 $\%$ RS with different rates of AGR in improving soil hydraulic conductivity is quite clears that it highly significant increased H.C. compared to (control soil) or other treatments. These results may be attributed to the role of soil amendments in increasing exchangeable $\mathrm{Ca}^{2+}$ which enhance the aggregation process and consequently increase apparent soil bulk volume, decrease soil bulk density and increase the efficiency of leaching processes. The results agreement with the results were obtained to those reported by Abd ElHamid et al. (2011); Gharaibeh et al., (2009) and Reading et al., (2012) consequently improving physical soil properties and the dynamic soil water movement. El-Sharawy el al., (2008). 


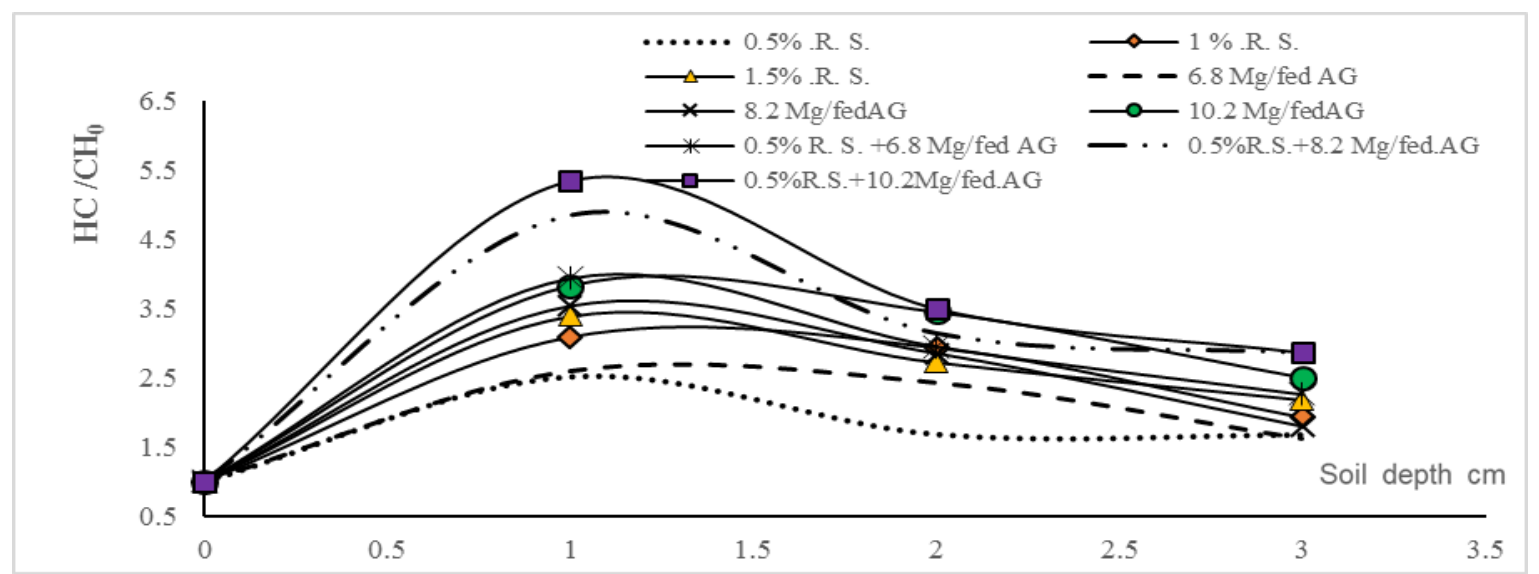

Fig. 2. Changes of HC under different treatments by RS, AG and their combination in 0-10, 10-20 and 20-30 cm soil layers

Statistical analysis indicated that there were positively significant differences among the different amendments. It was increasing significant affected by rates of amendments in three soil layers. These results Similar were obtained by Wahby (1986), who found that the addition of gypsum improved soil hydraulic conductivity. This increase in values of the H.C. may be attributed to increasing the proportion of large water stable aggregates on one hand and reducing the ESP and consequently diminishing the dispersion occurring in such sodic soils.

\section{Pore size distribution:}

Data of $0-10 \mathrm{~cm}$ soil depth presented in Table (3) and Figs $(3 \& 4)$, show that the effect of soil amendments RS, GR and their combination were increased of quickly drainable pores (QDP $28.8 \mu$ ) and water holding pores (WHP 8.86: $0.19 \mu$ ). These increases were $12.1,19.7 \& 62.9 \%$ and $12.5,23.4 \& 34$ \% for $0.5 \mathrm{RS}, 6.8$ ton.fed $^{-1}$ AGR and combination 0.5 RS+ 6.8 ton.fed $^{-1}$ AGR relatively to control, respectively. These values increased with increasing rates of these treatments, meanwhile the decrease of fine capillary pore (FCP $<0.19 \mu)$ by $7.65 \%$ compared to control soil. This may be due to the influence of salt concentration enhanced the coagulation of particles and create a renewed false aggregates that was accompanied by large pores, Mansour (2002), Data also showed that the effect of soil amendments application on pore size distribution of the studied soil. The application of soil amendments alone or in mixtures encouraged the formation of drainable pores and water holding pores on the account of fine capillary pores.

The obtained data indicate that there is an increase in values of the quickly drainable pores, which played a fundamental role during the salt leaching process, in all ameliorated soils comparing with soil control. The average values of (QDP) and (WHP) were increased in combination $0.5 \%$ RS+ each of $6.8,8.2$ and 10.2 ton.fed ${ }^{-1}$ agricultural gypsum treatments by 68.6 and $39.9 \%$ while the fine capillary pores were decreased by $6.23 \%$ compared to soil control. It's worth to mention that, the most efficient treatment here was $0.5 \% \mathrm{RS}$ +10.2 ton.fed ${ }^{1}{ }^{1}$ AGR. The most inferior treatment was application of RS or AG alone, even which was better than soil control. Also data reveal that, the treatment combine of $0.5 \% \mathrm{RS}+$ each of $6.8,8.2$ and 10.2 ton. fed $^{-1}$ AGR proved superior more than treated by (RS) or AG alone. At the same trend, of this result in 10-20 and 20-30 soil depth, but soil amendments are more effective in $0-10 \mathrm{~cm}$ soil depth than $10-20$ and $20-30 \mathrm{~cm}$ soil depth. This is due to the use of the gypsum easily released $\mathrm{Ca}^{2+}$ ions proved to be more effective than RS. Statistical analysis of data presented in Table $\left(6_{\mathrm{a}}, 6_{\mathrm{b}}\right.$, and $6_{c}$ ) showed that, the addition of gypsum was highly significant increasing the values of quickly drainable pores (QDP) and Water holding pores (WHP), meanwhile the fine capillary pores FCP represent insignificantly effect with RS, AGR and combine RS + AGR.7.62, 13.24 and $25.09 \%$ in comparison with the soil control $\left(\mathrm{PR}_{0}\right)$. However addition 6.8, 8.2 and 10.2 ton.fed ${ }^{-1}$ AG decrease PR values about 16.63, 21.74 and $27.06 \%$. In addition, combination $0.5 \% \mathrm{RS}+$ each of 6.8, 8.2 and 10.2 ton.fed ${ }^{-1} \mathrm{AG}$ were superior in reducing the soil penetration resistance about $31.35,34$ and $39.30 \%$ in comparison with the soil without treatments. Results also showed that mixing treated leads to reduce the soil penetration resistance in the $0-10 \mathrm{~cm}$ soil depth compared 10-20 and 20-30 cm soil depth. The average decreasing of PR values were 15.32, 21.81 and $34.86 \%$ of treatment alone RS or AGR and mixed of them respectively. On the other hand the values of PR 
increase with the increasing soil depth for all treatments Soil Penetration Resistance (PR):

Table (3) and Fig. (5) Showed decreases in the soil penetration resistance (PR) with increase the addition of quantity of rice straw (RS) at $20 \%$ from available water of all soil layer depths. Addition of $0.5,1$ and $1.5 \% \mathrm{RS}$ compared to control.

decreased the soil penetration resistance $(\mathrm{MPa})$ about while the treatments with the same amount of applications of RS or GR and their combined of them in soil layers (10-20 and 20-30 cm) depth recorded decreasing of soil penetration resistance about

Table 3. Effect of different rates of rice straw, gypsum and their combination amendments on Pores size distribution and penetration resistance (PR) at moisture content equivalent $20 \%$ of $\mathrm{AW}$ and the employed regression equation in each application

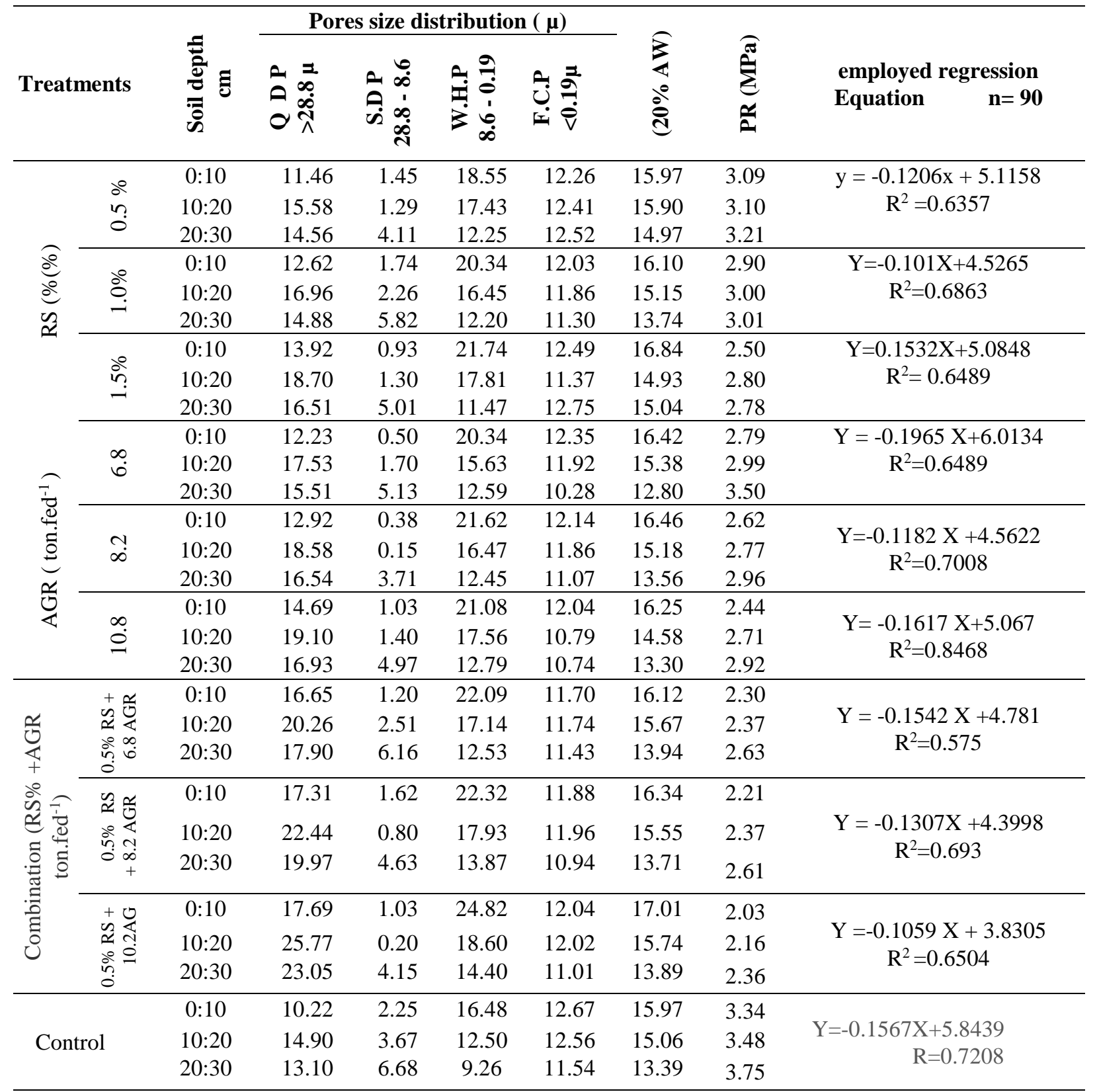

Where: Q. D. P = quickly drainable pores.

S. D. P. = slowly drainable pores

W.H.P = water holding capacity

F.C.P = fine capillary pores

$\mathrm{X}=$ moisture content at $20 \%$ from Available water.

$\mathrm{Y}=$ penetration resistance 


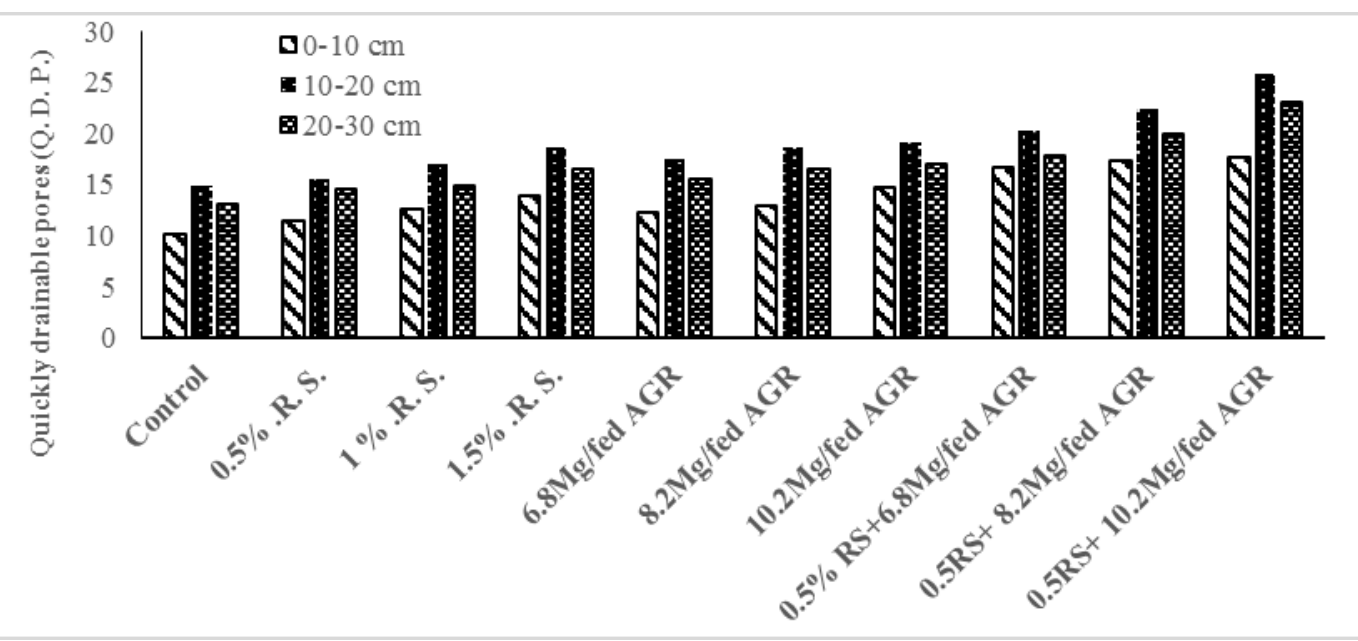

Fig. 3. Effect of different rates of RS, AGR and their combination on Q.D. P of the three soil layers

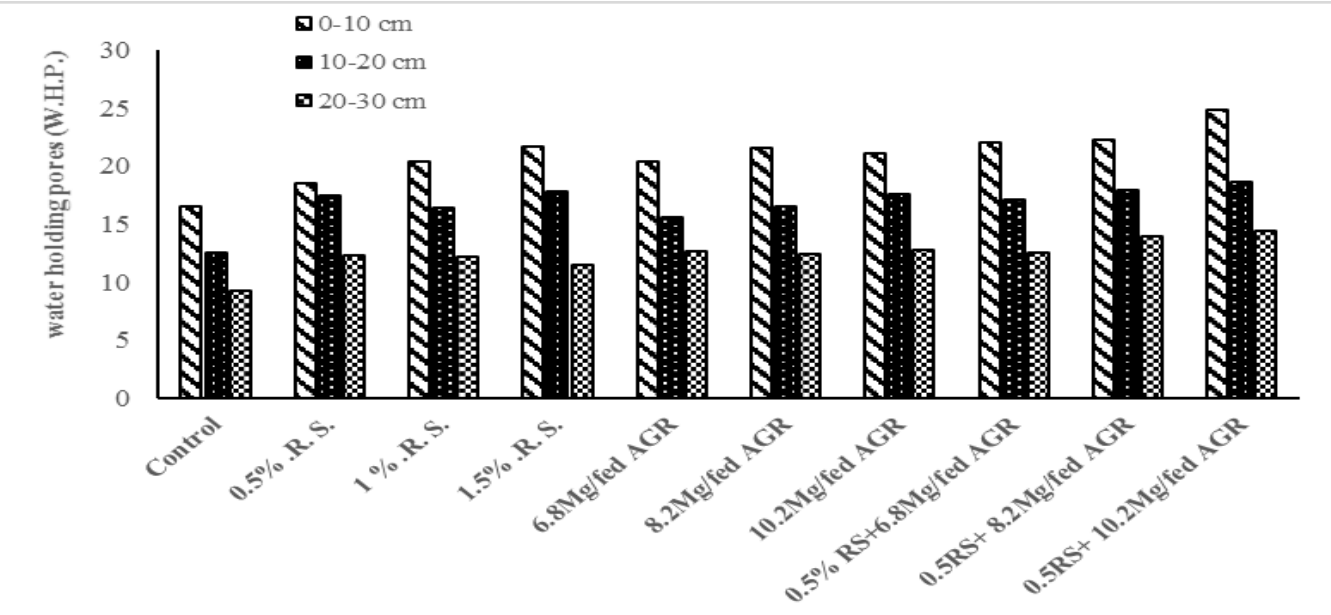

Fig. 4. Effect of different rates of RS, AGR and their combination on w. H.P of the three soil layers

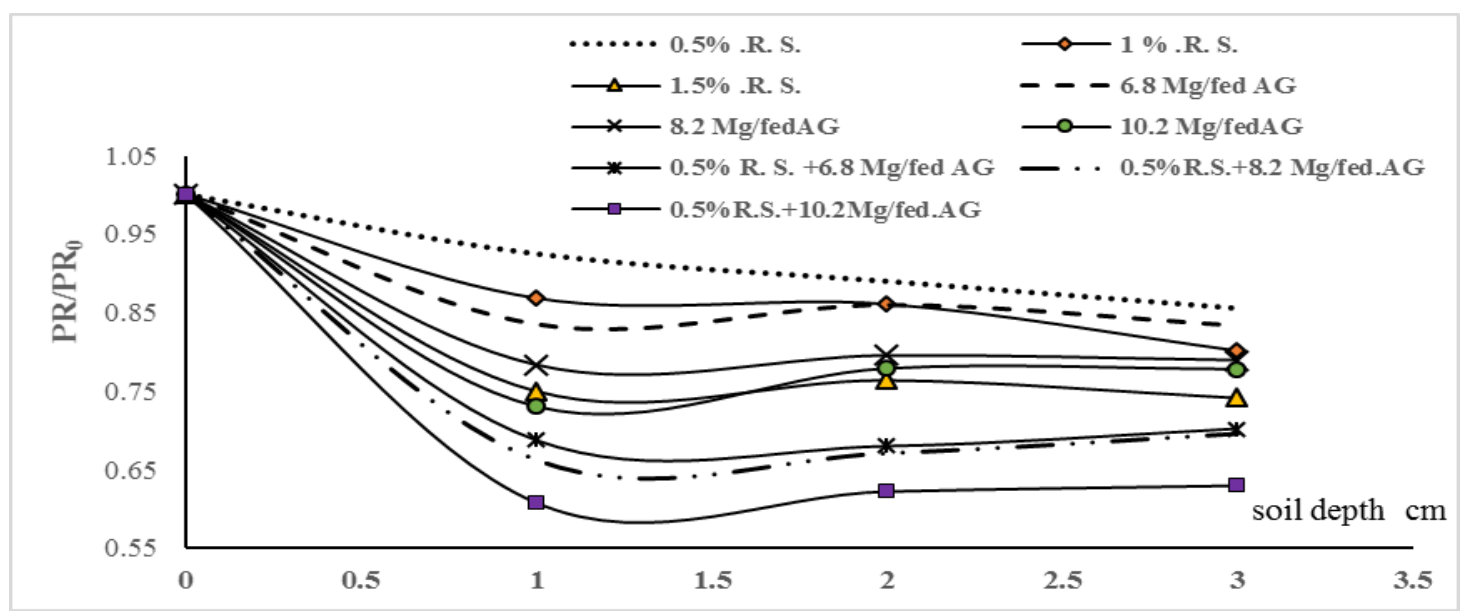

Fig. 5. Changes of PR rates under different treatments by RS, AG and their combination in 0-10, 10-20 and 20$30 \mathrm{~cm}$ soil layers 
$14.89,18.94 \& 33.98 \%$ and $19.95,16.59 \& 32.39 \%$ in comparison with the control soil respectively. Statistical analysis of data presented in Table $\left(6_{a}, 6_{b}\right.$, and $\left.6_{c}\right)$ showed that, the addition of RS or /and AGR highly significant decreased the values of PR, also decrease significantly affect with the increasing rates of RS, AGR and combine of RS + AGR.

\section{Soil chemical properties:}

\section{Soil pH:}

Data in Table (4) and Fig (6) have markedly decreased the value of $\mathrm{pH}$, from $0.5 \%$ rise straw treatment to combination $0.5 \%$ rice straw $+75 \%$ gypsum requirement as compared to soil control, especially in $0-10 \mathrm{~cm}$ soil depth. The decrease ranged from 0.5 and 1 unit, The application of RS $0.5,1$ and $1.5 \%$ lead to, soil $\mathrm{pH}$ values decreased by $7.9,7.7$ and 7.6, with reduction of 5.4, 7.7 and 9.3\%. In addition, $\mathrm{pH}$ values decreased to $7.8,7.6$ and 7.5 , by the application of agricultural gypsum $6.8,8.2$ and 10.2 ton.fed $^{-1}$, with reduction of $6.9,9.7$ and $10.5 \%$. Also, data referred that soil $\mathrm{pH}$ decreased to 7.6, 7.4 and 7.4, by application of $0.5 \%$ RS combined with each of $6.8,8.2$ and 10.2 ton.fed ${ }^{-1} \mathrm{AG}$, with reduction of $9.1,11.4$ and $12.1 \%$ as compared with control, respectively. In addition, data show that the decrease in the values of $\mathrm{pH}$ were more pronounced in the soil surface $(0-10 \mathrm{~cm})$ than the soil subsurface layers $(10-20$ and $20-30 \mathrm{~cm})$. This is mainly due to the dissolving of applied gypsum being most in the surface layer $(0-10 \mathrm{~cm})$ and less in the $10-20$ and 20 $30 \mathrm{~cm}$ soil depths.

Bhumbla and Abrol (1971) mentioned that the $\mathrm{pH}$ of surface soil layer $(0-10 \mathrm{~cm})$ was decreased with increasing applied gypsum. The decrease of soil $\mathrm{pH}$ was mainly attributed to the high amounts of sulfate ions released due to dissolution of applied gypsum. Application of AG and the consequent leaching slightly decreased $\mathrm{pH}$ values. This decreases didn't exceed 0.25 unit. Also, $\mathrm{pH}$ values of the different layers didn't show any constant trend and gave almost similar values. Khan et al., (2006) found that the soil $\mathrm{pH}$ decreased by AG application from 8.54 to 7.54. Moreover, Mahmoud (2011) recorded relative decreases in soil $\mathrm{pH}$ compared to the control which varied from 8.35 to 8.31 and 8.37 to 8.17 in case of the by applying gypsum and sulphur treatments, respectively.

\section{Electrical Conductivity (EC):}

Data in Table (4) and Fig (7) showed that concerning results of $0.5,1$ and $1.5 \%$ of RS application lead to reduce the salinity by $17.31,27.31$ and $30.78 \%$ of $0-10 \mathrm{~cm}$ soil depth compare to control. While, the values of salinity ratios of application 6.8, 8.2 and 10.2 ton.fed ${ }^{-1}$ AGR were reduced by $42.2,40$ and $39 \%$. In case of combination of $0.5 \%$ RS with each of $6.8,8.2$ and 10.2 ton.fed $^{-1}$ AGR, the values were decreased by $36.7, \quad 39.7$ and $47.15 \%$ compared to control, respectively. In the same order of rice straw treatments, it decreased EC values of 10-20 and 20-30 cm soil depth by $14.24,21.13 \& 27.67 \%$ and $18.37,20.24 \& 26.54 \%$, respectively. While the values of salinity ratio of application 6.8, 8.2 and 10.2 ton.fed $^{-1}$ AGR were reduced by $39.09,37.71 \& 39.52 \%$ and $27.59,26.39 \&$ $25.38 \%$ compared to control, respectively. In case of combination of $0.5 \%$ RS with each of $6.8,8.2$ and 10.2 ton.fed ${ }^{-1}$, the values were decreased by $29.78,32.73 \&$ $40.38 \%$ and $22.28,25.83 \& 29.97 \%$ compared to control, respectively. Such findings agree with those obtained by, Abdel-Fattah and Merwad (2016) and Saied et al. (2017) reported that, the addition of organic matter in conjunction with gypsum has been successful in reducing adverse soil properties associated with sodic soils.

Also__El-Shanawany (1985)_who reported that increasing gypsum application and leaching water greatly enhance the leaching of salts from a saline sodic soil. The surface layer deplete more soluble salts than the lower layers. This may be attributed to some of the leached salts from surface layer being accumulated in the deeper layers. The application of RS to saline sodic soil caused a decrease in soil salinity by average 55.4, 52.9 and $53 \%$. While, application of AG to the saline sodic soil caused decreased in soil salinity by average $64.4,63.5$ and $55.8 \%$ in $0-10,10-20$ and $20-30 \mathrm{~cm}$ soil depth, respectively as compared to EC value of control. The values of EC for $0-10,10-20$ and $20-30 \mathrm{~cm}$ soil depth of the soil combination were decreased by average 64.9, 60.8 and 55.6\%, respectively. These results agree with those of Wahby (1986) who reported that gypsum application helped salt leaching through soil profile. Also, the application of gypsum was most effective in the reclamation of sodic soils. Statistical analysis of data presented in Table $\left(6_{\mathrm{a}}, 6_{\mathrm{b}}\right.$, and $\left.6_{\mathrm{c}}\right)$ showed that, the addition of RS or /and AGR highly significant decreased the values of EC, also decrease significantly affect with the increasing rates of RS, AGR and RS + AGR.

This agree with Ghulam et al. (2011) who found that application of agricultural gypsum was most effective in the reclamation of sodic soils, beside of improving the chemical properties $(\mathrm{pH}$, EC, SAR and ESP with increasing levels added from GR.) to the saline sodic soil. Such finding agree with those obtained by ElShnawany (1985) who reported that gypsum application and increasing leaching water greatly enhanced the leaching of salts from a saline sodic soil. 
Table 4. Effect of different rates of rice straw, gypsum and their combination amendments on some chemical properties soil in EI Tina plain (soil paste)

\begin{tabular}{|c|c|c|c|c|c|c|c|c|c|c|c|c|c|c|}
\hline \multirow{2}{*}{\multicolumn{2}{|c|}{ Treatments }} & \multirow{2}{*}{ 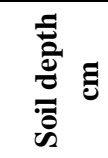 } & \multirow{2}{*}{ T. } & \multirow{2}{*}{ ن } & \multicolumn{4}{|c|}{ Soluble cations ( meq/L) } & \multicolumn{4}{|c|}{ Soluble anions (meq/L) } & \multirow[t]{2}{*}{ SAR } & \multirow{2}{*}{$\begin{array}{c}\text { ESP } \\
\%\end{array}$} \\
\hline & & & & & + & + & $\mathbf{a}^{+}$ & $\mathbf{K}^{+}$ & $O_{3}^{-2}$ & $\mathrm{HCO}$ & $\mathrm{Cl}^{-}$ & $\mathrm{SO}_{4}^{-2}$ & & \\
\hline \multirow{9}{*}{$\begin{array}{l}\widehat{d} \\
\text { is } \\
\dot{n}\end{array}$} & \multirow{3}{*}{ 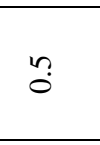 } & $0: 10$ & 7.92 & 16.44 & 37.18 & 19.11 & 101.94 & 6.15 & 0.00 & 6.37 & 103.32 & 54.69 & 19.22 & 21.31 \\
\hline & & $10: 20$ & 8.07 & 17.05 & 38.76 & 20.12 & 07.82 & 3.80 & 0.00 & 8.10 & 125.45 & 6.95 & 19.87 & 21.91 \\
\hline & & $20: 30$ & 8.12 & 16.33 & 32.32 & 15.58 & 110.19 & 5.25 & 0.00 & 8.77 & 114.60 & יוסקנד & 22.52 & 24.21 \\
\hline & \multirow{3}{*}{$\stackrel{\circ}{\circ}$} & $0: 10$ & 7.73 & 14.45 & 41.37 & 19.94 & 76.94 & 6.25 & 0.00 & 9.96 & 91.13 & 43.41 & 13.90 & 16.13 \\
\hline & & $10: 20$ & 8.02 & 15.68 & 41.36 & 15.44 & 95.85 & 4.15 & 0.00 & 8.07 & 97.00 & 3.73 & 17.99 & 20.17 \\
\hline & & $20: 30$ & 8.06 & 15.96 & 39.04 & 17.12 & 97.05 & 6.39 & 0.00 & 8.58 & 96.76 & 4.26 & 18.31 & 20.48 \\
\hline & \multirow{3}{*}{$\because$} & $0: 10$ & 7.59 & 13.76 & 42.65 & 0.30 & 70.54 & 4.11 & .00 & 5.56 & .97 & 7 & 12.57 & 14.74 \\
\hline & & $10: 20$ & 7.81 & 14.38 & 44.10 & 14.30 & 81.04 & 4.36 & 0.00 & 7.20 & 83.24 & 36 & 15.00 & 17.26 \\
\hline & & $20: 30$ & 7.89 & 14.70 & 41.42 & 16.73 & 82.57 & 6.2 & 0.00 & 7. & 89. & 1 & 15.31 & 17.58 \\
\hline \multirow{9}{*}{ 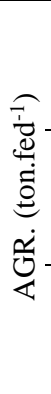 } & \multirow{3}{*}{$\stackrel{\infty}{6}$} & $0: 10$ & 7.79 & 11.49 & 33.81 & & & & 0.00 & & & & 12 & 14 \\
\hline & & $10: 20$ & 7.86 & 12.11 & 34.22 & 13.53 & 69.52 & 3.82 & 0.00 & 7.22 & 59.69 & & 14.23 & 16.48 \\
\hline & & $20: 30$ & 7.88 & 14.49 & 44.36 & 17.85 & 78.35 & 4.34 & 0.00 & 7.97 & 77.23 & 0 & 14.05 & 16.29 \\
\hline & \multirow{3}{*}{$\stackrel{\infty}{\infty}$} & $0: 10$ & 7.56 & 11.93 & 38.18 & 18.41 & 56.70 & 6.04 & 0.00 & 6. & & & 10.66 & 12.64 \\
\hline & & $10: 20$ & 7.70 & 12.38 & 42.77 & 11.15 & 65.44 & 4.47 & 0.00 & 6.17 & 46.10 & 71.56 & 12.60 & 14.77 \\
\hline & & $20: 30$ & 7.74 & 14.73 & 46.21 & 18.46 & 76.62 & 6.00 & 0.00 & 7.18 & 71.50 & 68.61 & 13.47 & 15.69 \\
\hline & \multirow{3}{*}{$\stackrel{?}{\varrho}$} & $0: 10$ & 7.49 & 12.23 & 44.33 & 17.68 & 53.83 & 6.4 & 0.00 & 6. & 51.29 & 4 & 9.67 & 11.50 \\
\hline & & $10: 20$ & 7.62 & 12.02 & 54. & 11.09 & 60. & 3. & 0.00 & & 4 & & 10 & 12.55 \\
\hline & & $20: 30$ & 7.69 & 14.93 & 49.70 & 20.66 & 74.32 & 4.64 & 0.00 & 7.05 & 65.79 & 6.48 & 12.53 & 14.69 \\
\hline \multirow{9}{*}{ 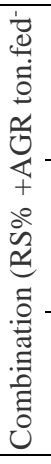 } & \multirow{3}{*}{ 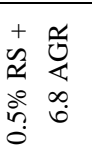 } & $0: 10$ & 7.61 & 12.58 & 41.72 & 17.60 & 60.06 & 6.44 & 0.00 & 4.11 & 46.87 & 74.83 & 11.03 & 13.05 \\
\hline & & $10: 20$ & 7.58 & 13.96 & 47.92 & 20.56 & 66.90 & 4.21 & 0.00 & 5.69 & 58.38 & 75.52 & 11.43 & 13.50 \\
\hline & & $20: 30$ & 7.65 & 15.55 & 49.47 & 20.49 & 79.47 & 6.08 & 0.00 & 5.92 & 75 & 6 & 13.44 & 15.65 \\
\hline & \multirow{3}{*}{ 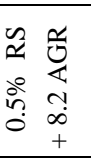 } & $0: 10$ & 7.42 & 1 & 4 & & 49.13 & & 0.00 & & & 73.33 & 8.62 & 10.28 \\
\hline & & $10: 20$ & 7.52 & 13.37 & 46.75 & 23.22 & 60.25 & 3.53 & 0.00 & 5.83 & 55.85 & 72.06 & 10.19 & 12.10 \\
\hline & & $20: 30$ & 7.56 & 14.84 & 52.22 & 18.01 & 73.31 & 5.00 & 0.00 & 6.83 & 66.61 & 74.97 & 12.37 & 14.52 \\
\hline & \multirow{3}{*}{ 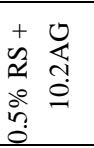 } & $0: 10$ & 7.36 & 10.51 & 42.12 & 15.82 & & & 0.00 & & & & 8.02 & 9.56 \\
\hline & & $10-20$ & 7.40 & 11.85 & 53.70 & 11.26 & 50.13 & 3.43 & 0.00 & 4.80 & 45.14 & 68.58 & 8.80 & 10.49 \\
\hline & & $20-30$ & 7.43 & 14.01 & 49.57 & 21.02 & 64.33 & 5.09 & 0.00 & 6.36 & 56.21 & 77.56 & 10.83 & 12.83 \\
\hline \multirow{3}{*}{\multicolumn{2}{|c|}{ Control }} & $0: 10$ & 8.37 & 19.88 & 29.1 & 17.75 & 146.93 & 4.34 & 0.00 & 11.39 & 151.24 & 36 & 31.33 & 31.30 \\
\hline & & $10: 20$ & 8.42 & 19.88 & 29.77 & 14.89 & 149.87 & 4.31 & 0.00 & 11.39 & 149.88 & 37.57 & 31.72 & 31.28 \\
\hline & & $20: 30$ & 8.40 & 20.01 & 29.25 & 15.17 & 150.07 & 4.56 & 0.00 & 11.39 & 150.24 & 38.42 & 31.84 & 31.37 \\
\hline
\end{tabular}

\section{Exchangeable sodium percent (ESP):}

Table (4) and Fig (8) showed decreases in exchangeable $\mathrm{Na}$ percentage was recorded with all application RS, AGR either individual or combine them. The treatment of gypsum combination $0.5 \% \mathrm{RS}+10.2$ ton.fed ${ }^{-1}$ AGR was more effective in decreasing ESP than application RC or AGR alone, where ESP values decreased to $69.3,66.3$ and $59.1 \%$ in the $0-10,10-20$ and $20-30 \mathrm{~cm}$ soil depth respectively compared to control. Also These results indicate that application by either $1.5 \%$ RS or 10.2 ton.fed $^{-1}$ GR or combine $0.5 \%$ RS +10.2 ton.fed ${ }^{-1}$ AGR increase the Hydraulic conductivity by $2.18,2.45 \& 3.43$ times and $1.96,2.48$
\& 2.58 times in the $0-10$ and $10-20 \mathrm{~cm}$ soil depth respectively compare to control. These results due to water percolation was faster in soil with treated with gypsum. Also application of combine RS + AGR gave the highest increase in the H.C, this may be increasing aggregation and the proportion of water stable aggregates. ESP values were decreased by $(31.9,30$ and $22.8 \%),(53.6,47.3$ and $48.1 \%)$ and $(58.3,56.9$ and $50.1 \%$ ) for $0-10,10-20$ and $20-30 \mathrm{~cm}$ soil depth application by $0.5,1$ and $1.5 \% \mathrm{RS}, 6.8,8.2$ and 10.2 ton.fed ${ }^{-1}$ AGR and combine $0.5 \% \mathrm{RS}+$ each of $6.8,8.2$ and 10.2 ton.fed ${ }^{-1}$ GR treatments respectively, relatively 


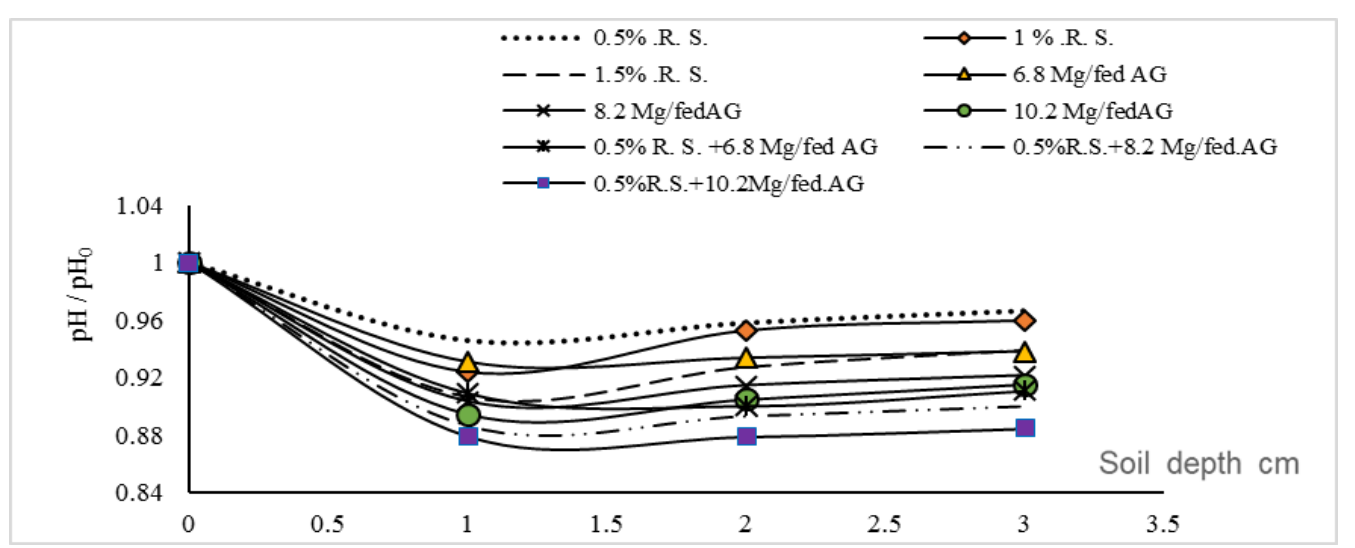

Fig. 6. Changes of pH rates under different treatments by RS, AG and their combination in 0-10, 10-20 and 20$30 \mathrm{~cm}$ soil layers

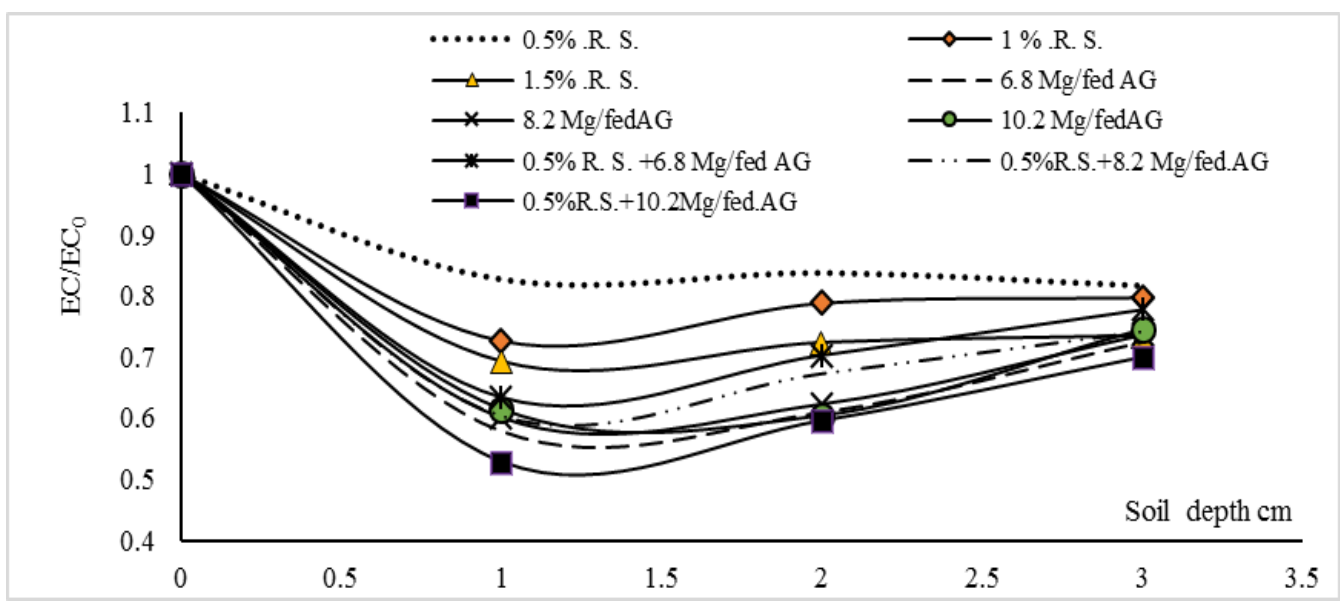

Fig. 7. Changes of EC rates under different treatments by RS, AG and their combination in 0-10, 10-20 and 20$30 \mathrm{~cm}$ soil layer

the ESP value of initial soil. ESP values was decrease with increasing the rates of treatments and the highest decrease of ESP values was with the combine $0.5 \%$ RS +10.2 ton.fed ${ }^{-1}$ AGR treatment.

These results may be due to the role of gypsum in providing $\mathrm{Ca}^{2+}$ cation to replace the exchangeable $\mathrm{Na}^{+}$ on the exchange positions as observed by Sharma and Minhas (2005). This is most probably due to its rather contain adequate contents of $\mathrm{Ca}^{2+}$ ions. It could be attributed to presence of relatively high amounts of $\mathrm{Ca}^{2+}$ ion as a well-established practice for the amelioration and management of sodium saturated water/soils Amezketa et al. (2005). Also, ESP values decrease by leaching without using amendments was not considerable and the soil remained sodic with highly ESP values. However, the final ESP obtained after leaching with amendments gave the highest decrease \% in ESP values by using combine $0.5 \% \mathrm{RS}+$ each of 6.8, 8.2 and 10.2 ton.fed $^{-1}$ AGR. This effect is more pronounced in the surface layer. Surface applied water would pass through the surface applied amendment and infiltrate the top layers allowing exchange process between $\mathrm{Ca}^{2+}$ and $\mathrm{Na}^{+}$(El-Sharawy et al., 2008). ESP values increased with increasing soil depth with similar trend to EC and SAR, agreement with Moustafa (2005) who found that the application of gypsum, farmyard manure and gypsum + farmyard manure lead to decrease ESP with the increasing rates of gypsum + farmyard manure treatment. Data in table $\left(6_{a}, 6_{b}\right.$, and $\left.6_{c}\right)$ reveal that, it was decrease highly significant differ among amendments, also among different rates of amendments in each of $0-10,10-20$ and $20-30 \mathrm{~cm}$ soil layers.

\section{Spinach growth yield:-}

Table (5) showed that values of fresh weight of yield / pot, increased significantly with the application of both RS, AG and their combination as compared to control treatment Also, results indicated that fresh Spinach yield increased gradually by increasing the rates of $\mathrm{RS}, \mathrm{AG}$ 


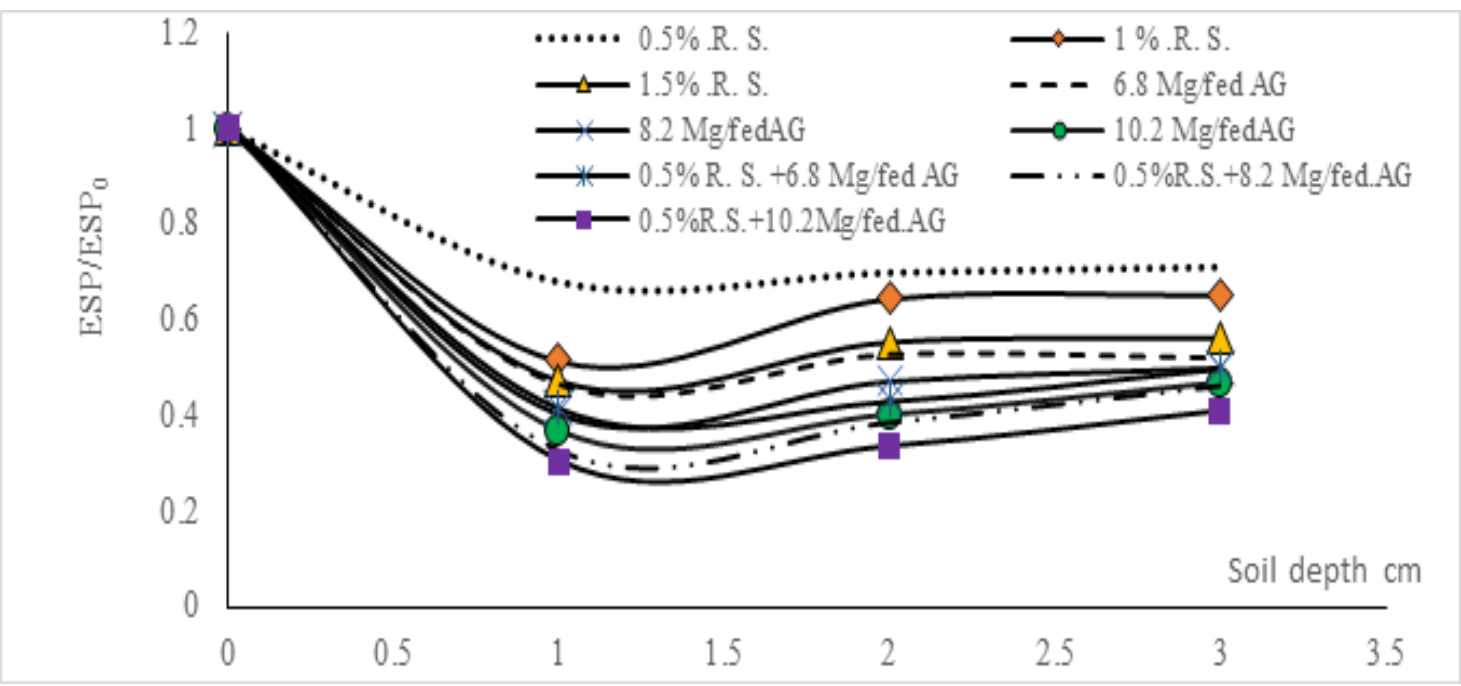

Fig. 8. Changes of ESP rates under different treatments in 0-10, 10-20 and 20-30 cm soil layers

conditioners. Moreover, combine of RS+ AG treatment had recorded the highest values of fresh weight yield as compared to those given by AG or RS conditioners. The obtained results that good evidence that AG application promotes growth of plants and it has been found to have a positive effect on productivity of fresh Spinach yield. There was an increasing interest in the potential use of AG as soil amendment, where the addition of AG improves the soil physical and chemical properties. The fresh yield of Spinach yield was higher in soils receiving AGR amendment as compared to RS. The highest shoot Spinach yield was, obtained by treatment different rates of RS, AGR and combine of $0.5 \% \mathrm{RS}+$ each of $6.8,8.2$ and 10.2 ton. fed $^{-1}$ AGR, where the increasing rates of fresh weight yield were $37.32,71.58$ $\& 82.58$ of $0.5,1$ and $1.5 \% \mathrm{RS}, 71.58,115.76 \&$ $123.23 \%$ of AGR and 127.62, $131.37 \& 135.79$ of combine $0.5 \% \mathrm{RS}+6.8,8.2$ and 10.2 ton/ $\mathrm{fed}^{-1} \mathrm{AGR}$ respectively, compared to control.

Table 5. Effect of different rates of rice straw, gypsum and their combination amendments on fresh spinach yield productivity.

\begin{tabular}{|c|c|c|c|c|c|}
\hline Treatments & rates & $\begin{array}{l}\text { Fresh Wei.(Y. 1) } \\
\text { Per.gm/ pot }\end{array}$ & $\begin{array}{l}\text { Rank Mean } \\
\text { of treatment }\end{array}$ & $\begin{array}{c}\text { Fresh Wei. (Y. 1) } \\
\text { Per. Kg/ fed }\end{array}$ & $\begin{array}{l}\text { Rank Mean of } \\
\text { treatment }\end{array}$ \\
\hline \multirow{3}{*}{ R. S (\%) } & $0.5 \%$ & $44.73 \mathrm{~h}$ & \multirow{3}{*}{$\mathrm{c}$} & $3825.6 \mathrm{~h}$ & \multirow{3}{*}{$\mathrm{c}$} \\
\hline & $1.0 \%$ & $55.85 \mathrm{~g}$ & & $4776.7 \mathrm{~g}$ & \\
\hline & $1.5 \%$ & $59.43 \mathrm{f}$ & & $5082.9 \mathrm{f}$ & \\
\hline \multirow{3}{*}{ AGR. (ton.fed $\left.{ }^{-1}\right)$} & 6.8 ton/fed & $55.85 \mathrm{~g}$ & \multirow{3}{*}{$\mathrm{b}$} & $4776.7 \mathrm{~g}$ & \multirow{3}{*}{$\mathrm{b}$} \\
\hline & 8.2 ton/fed & $70.23 \mathrm{e}$ & & $6006.6 \mathrm{e}$ & \\
\hline & 10.2 ton/fed & $72.66 \mathrm{~d}$ & & $6214.4 \mathrm{~d}$ & \\
\hline Combination & $0.5 \% \mathrm{RS}+6.8 \mathrm{AG}$ & $74.09 \mathrm{c}$ & \multirow{3}{*}{$\mathrm{a}$} & $6336.7 \mathrm{c}$ & \multirow{3}{*}{$\mathrm{a}$} \\
\hline$(\mathrm{RS} \%+\mathrm{AGR}$ & $0.5 \% \mathrm{RS}+8.2 \mathrm{AG}$ & $75.31 \mathrm{~b}$ & & $6441.1 \mathrm{~b}$ & \\
\hline ton.fed ${ }^{-1}$ ) & $0.5 \% \mathrm{RS}+10.2 \mathrm{AG}$ & $76.75 \mathrm{a}$ & & $6564.2 \mathrm{a}$ & \\
\hline \multicolumn{2}{|l|}{ Control } & $32.55 \mathrm{i}$ & $\mathrm{d}$ & $2783.9 \mathrm{i}$ & $\mathrm{d}$ \\
\hline \multicolumn{2}{|l|}{ Sign } & $* * *$ & $* * *$ & $* * *$ & $* * *$ \\
\hline \multicolumn{2}{|l|}{ LSD $_{0.05}$ of rates } & 1.22 & 0.702 & 18.25 & 10.54 \\
\hline
\end{tabular}

Fresh weight. Y 1 = fresh weight of yield per gm / pot of treatments (productivity/ treatment).

Fresh weight. Y 2 = fresh weight of yield per $\mathrm{kg} / \mathrm{fed}$. of treatments 
Table 6a. Statistical analysis ANOVA of some physical and chemical soil properties under gypsum, rice straw ant their combination amendments and their rates for $0-10 \mathrm{~cm}$

\begin{tabular}{|c|c|c|c|c|c|c|c|c|c|c|c|c|c|}
\hline \multicolumn{2}{|c|}{ Soil property } & BD & F.C. & A.W & HC & QDP & SDP & WHP & FCP & PR & Ec & ESP & pH \\
\hline \multirow{2}{*}{ Treatment } & Sign. & $* *$ & $* *$ & $* *$ & $* * *$ & $* *$ & $*$ & $* *$ & $\mathrm{~ns}$ & $* *$ & $* * *$ & $* * *$ & $* *$ \\
\hline & $\operatorname{LSD}_{0.05}$ & 0.09 & 0.53 & 0.53 & 0.105 & 0.53 & 0.09 & 0.88 & 0.53 & 0.105 & 0.23 & 0.47 & 0.09 \\
\hline \multirow{2}{*}{ Rates } & Sign. & $*$ & $*$ & $*$ & $* *$ & $*$ & ns & $*$ & ns & $*$ & $* *$ & $* *$ & $*$ \\
\hline & $\mathrm{LSD}_{0.05}$ & 0.15 & 0.91 & 0.91 & 0.18 & 0.91 & 0.55 & 1.52 & 0.91 & 0.18 & 0.40 & 0.81 & 0.15 \\
\hline \multicolumn{14}{|c|}{ Rank Mean of treatments addition } \\
\hline R. S. & & $\mathrm{b}$ & $\mathrm{c}$ & $\mathrm{c}$ & $\mathrm{c}$ & $\mathrm{c}$ & $\mathrm{b}$ & $\mathrm{b}$ & $\mathrm{ab}$ & $\mathrm{b}$ & $\mathrm{b}$ & $\mathrm{c}$ & $\mathrm{c}$ \\
\hline G.R.A & & $\mathrm{b}$ & $\mathrm{b}$ & $\mathrm{b}$ & $\mathrm{b}$ & $\mathrm{b}$ & $\mathrm{c}$ & $\mathrm{b}$ & $a b$ & $\mathrm{c}$ & $\mathrm{c}$ & $\mathrm{b}$ & $\mathrm{b}$ \\
\hline $\mathrm{RS}+\mathrm{GRA}$ & & $\mathrm{c}$ & a & $\mathrm{a}$ & $\mathrm{a}$ & $\mathrm{a}$ & $\mathrm{b}$ & $\mathrm{a}$ & $\mathrm{b}$ & $\mathrm{d}$ & $\mathrm{c}$ & $\mathrm{d}$ & $\mathrm{d}$ \\
\hline Control & & $\mathrm{a}$ & $\mathrm{d}$ & $\mathrm{d}$ & $\mathrm{d}$ & $\mathrm{d}$ & $\mathrm{a}$ & $\mathrm{c}$ & $\mathrm{a}$ & $\mathrm{a}$ & $\mathrm{a}$ & $\mathrm{a}$ & $\mathrm{a}$ \\
\hline \multicolumn{14}{|c|}{ Rank Mean of treatments rates addition } \\
\hline \multirow{3}{*}{ RS } & $0.5 \%$ & $a b$ & $\mathrm{e}$ & $\mathrm{e}$ & $\mathrm{g}$ & $\mathrm{e}$ & $\mathrm{b}$ & $\mathrm{d}$ & $\mathrm{ab}$ & $\mathrm{b}$ & $\mathrm{b}$ & $\mathrm{b}$ & $\mathrm{b}$ \\
\hline & $1 \%$ & $\mathrm{bc}$ & $\mathrm{d}$ & $\mathrm{d}$ & $\mathrm{f}$ & d & $\mathrm{b}$ & $\mathrm{c}$ & $a b$ & $\mathrm{c}$ & $\mathrm{c}$ & $\mathrm{c}$ & $\mathrm{cd}$ \\
\hline & $1.5 \%$ & $\mathrm{bc}$ & $\mathrm{b}$ & $\mathrm{b}$ & ef & $\mathrm{c}$ & $\mathrm{cd}$ & $\mathrm{bc}$ & $a b$ & $\mathrm{e}$ & $\mathrm{d}$ & $\mathrm{d}$ & de \\
\hline \multirow{3}{*}{$\begin{array}{c}\text { AGR } \\
\text { (ton. fed } \\
\text { 1) }\end{array}$} & 6.8 & $\mathrm{~b}$ & $\mathrm{~d}$ & $\mathrm{~d}$ & $\mathrm{~g}$ & $\mathrm{de}$ & $\mathrm{bc}$ & $\mathrm{c}$ & $a b$ & $\mathrm{~cd}$ & $\mathrm{~g}$ & $\mathrm{~d}$ & $\mathrm{bc}$ \\
\hline & 8.2 & $\mathrm{bc}$ & bc & $\mathrm{bc}$ & de & $\mathrm{d}$ & $\mathrm{bc}$ & $\mathrm{bc}$ & $a b$ & $\mathrm{de}$ & $\mathrm{f}$ & $\mathrm{e}$ & ef \\
\hline & 10.2 & $\mathrm{bc}$ & $\mathrm{cd}$ & $\mathrm{cd}$ & $\mathrm{cd}$ & $\mathrm{c}$ & $\mathrm{cd}$ & $\mathrm{bc}$ & $a b$ & ef & ef & $\mathrm{e}$ & $\mathrm{fg}$ \\
\hline \multirow{3}{*}{$\mathrm{RS}+\mathrm{AGR}$} & $0.5 \%+6.8$ & $\mathrm{bc}$ & $\mathrm{bc}$ & $\mathrm{bc}$ & $\mathrm{c}$ & $\mathrm{b}$ & $\mathrm{cd}$ & $\mathrm{b}$ & $\mathrm{b}$ & fg & $\mathrm{e}$ & $\mathrm{f}$ & de \\
\hline & $0.5 \%+8.2$ & $\mathrm{bc}$ & $\mathrm{b}$ & $\mathrm{b}$ & $\mathrm{b}$ & $a b$ & $\mathrm{~cd}$ & $\mathrm{~b}$ & $\mathrm{~b}$ & $\mathrm{gh}$ & $\mathrm{f}$ & $\mathrm{g}$ & $\mathrm{fg}$ \\
\hline & $0.5 \%+10.2$ & $\mathrm{c}$ & $\mathrm{a}$ & $\mathrm{a}$ & $\mathrm{a}$ & $\mathrm{a}$ & de & $\mathrm{a}$ & $a b$ & $\mathrm{~h}$ & $\mathrm{~h}$ & $\mathrm{~g}$ & $\mathrm{~g}$ \\
\hline control & & $a$ & $f$ & $f$ & $\mathrm{~h}$ & $f$ & $a$ & $\mathrm{e}$ & $\mathrm{a}$ & $\mathrm{a}$ & $\mathrm{a}$ & $\mathrm{a}$ & $\mathrm{a}$ \\
\hline
\end{tabular}

Table 6b. Statistical analysis ANOVA of some physical and chemical soil properties under gypsum, rice straw ant their combination amendments and their rates for $10-20 \mathrm{~cm}$

\begin{tabular}{|c|c|c|c|c|c|c|c|c|c|c|c|c|c|}
\hline \multicolumn{2}{|c|}{ Soil property } & BD & F.C. & A.W & $\mathrm{HC}$ & QDP & SDP & WHP & FCP & PR & Ec & ESP & pH \\
\hline \multirow{2}{*}{ Treatment } & Sign. & $* *$ & $* *$ & $* *$ & $* *$ & $* * *$ & $* *$ & $* *$ & $*$ & $* *$ & $* *$ & $* * *$ & $* *$ \\
\hline & $\mathrm{LSD}_{0.05}$ & .035 & 0.53 & 0.53 & 0.09 & 0.53 & 0.53 & 1.02 & 0.82 & 0.105 & 1.20 & 0.9 & 0.09 \\
\hline \multirow{2}{*}{ Rates } & Sign. & $*$ & $*$ & $*$ & $* *$ & $* *$ & $*$ & ns & ns & $*$ & $*$ & $* *$ & $*$ \\
\hline & $\mathrm{LSD}_{0.05}$ & 0.02 & 0.98 & 0.91 & 0.15 & 0.91 & 0.91 & 1.76 & 1.42 & 0.18 & 0.70 & 1.55 & 0.15 \\
\hline \multicolumn{14}{|c|}{ Rank Mean of treatments addition } \\
\hline & $\mathrm{b}$ & $\mathrm{b}$ & $\mathrm{b}$ & $\mathrm{c}$ & $\mathrm{c}$ & $\mathrm{b}$ & $\mathrm{ab}$ & $\mathrm{ab}$ & $\mathrm{b}$ & $\mathrm{b}$ & $\mathrm{b}$ & $\mathrm{b}$ \\
\hline \multicolumn{2}{|l|}{ G.R.A } & $\mathrm{c}$ & $\mathrm{c}$ & b & $\mathrm{b}$ & $\mathrm{b}$ & $\mathrm{c}$ & $\mathrm{b}$ & $\mathrm{b}$ & $\mathrm{c}$ & $\mathrm{d}$ & $\mathrm{c}$ & $\mathrm{c}$ \\
\hline \multicolumn{2}{|l|}{ RS+GRA } & $\mathrm{d}$ & $\mathrm{a}$ & $\mathrm{a}$ & $\mathrm{a}$ & $\mathrm{a}$ & $\mathrm{bc}$ & $\mathrm{a}$ & $\mathrm{ab}$ & $\mathrm{d}$ & $\mathrm{c}$ & $\mathrm{d}$ & $\mathrm{d}$ \\
\hline \multicolumn{2}{|l|}{ Control } & $\mathrm{a}$ & d & $\mathrm{c}$ & $\mathrm{d}$ & $\mathrm{d}$ & $\mathrm{a}$ & $\mathrm{c}$ & $\mathrm{a}$ & $\mathrm{a}$ & $\mathrm{a}$ & $\mathrm{a}$ & $\mathrm{a}$ \\
\hline \multicolumn{14}{|c|}{ Rank Mean of treatments rates addition } \\
\hline \multirow{3}{*}{$\mathrm{RS} \%$} & $0.5 \%$ & $\mathrm{~b}$ & $a b$ & de & $\mathrm{e}$ & $\mathrm{f}$ & $\mathrm{d}$ & $\mathrm{ab}$ & $\mathrm{ab}$ & $\mathrm{b}$ & $\mathrm{b}$ & $\mathrm{b}$ & $\mathrm{b}$ \\
\hline & $1 \%$ & $\mathrm{c}$ & $\mathrm{cd}$ & $\mathrm{f}$ & $\mathrm{bc}$ & $\mathrm{e}$ & bc & $\mathrm{bc}$ & bc & b & $\mathrm{c}$ & $\mathrm{c}$ & b \\
\hline & $1.5 \%$ & $\mathrm{~d}$ & $\mathrm{bc}$ & $\mathrm{cd}$ & $\mathrm{c}$ & d & $\mathrm{d}$ & $a b$ & $\mathrm{bc}$ & $\mathrm{c}$ & d & $\mathrm{d}$ & $\mathrm{cd}$ \\
\hline \multirow{3}{*}{$\begin{array}{c}\text { GR. } \\
\left(\text { tonfed }^{-1}\right)\end{array}$} & 6.8 & $\mathrm{~b}$ & $\mathrm{~d}$ & de & $\mathrm{d}$ & $\mathrm{e}$ & $\mathrm{bc}$ & $\mathrm{c}$ & $\mathrm{bc}$ & $\mathrm{b}$ & $\mathrm{f}$ & $\mathrm{d}$ & $\mathrm{c}$ \\
\hline & 8.2 & $\mathrm{c}$ & $\mathrm{cd}$ & ef & $\mathrm{c}$ & d & $\mathrm{e}$ & $\mathrm{bc}$ & $\mathrm{bc}$ & $\mathrm{c}$ & ef & e & de \\
\hline & 10.2 & d & $\mathrm{cd}$ & $a b$ & $\mathrm{a}$ & d & $\mathrm{cd}$ & $a b$ & $\mathrm{c}$ & $\mathrm{c}$ & $\mathrm{f}$ & $\mathrm{f}$ & ef \\
\hline \multirow{3}{*}{$\mathrm{RS}+\mathrm{GR}$} & $0.5 \%+6.8$ & $\mathrm{~d}$ & $\mathrm{c}$ & $\mathrm{a}$ & $\mathrm{bc}$ & $\mathrm{c}$ & $\mathrm{b}$ & $a b$ & $\mathrm{bc}$ & $d$ & $\mathrm{~d}$ & ef & ef \\
\hline & $0.5 \%+8.2$ & $\mathrm{e}$ & $a b$ & $\mathrm{~cd}$ & $\mathrm{~b}$ & b & de & $a b$ & $\mathrm{bc}$ & $\mathrm{d}$ & de & $\mathrm{f}$ & $\mathrm{fg}$ \\
\hline & $0.5 \%+10.2$ & $\mathrm{e}$ & $\mathrm{a}$ & $\mathrm{bc}$ & $\mathrm{a}$ & $\mathrm{a}$ & $\mathrm{e}$ & $\mathrm{a}$ & $\mathrm{bc}$ & $\mathrm{e}$ & $\mathrm{f}$ & g & $\mathrm{g}$ \\
\hline control & & $\mathrm{a}$ & $\mathrm{e}$ & $\mathrm{g}$ & $\mathrm{f}$ & $\mathrm{f}$ & $\mathrm{a}$ & $\mathrm{d}$ & $\mathrm{a}$ & $\mathrm{a}$ & $\mathrm{a}$ & $\mathrm{a}$ & $\mathrm{a}$ \\
\hline
\end{tabular}

Table 6. Statistical analysis ANOVA of some physical and chemical soil properties under gypsum, rice straw ant their combination amendments and their rates for $20-30 \mathrm{~cm}$ 


\begin{tabular}{cccccccccccccc}
\hline \multicolumn{2}{c}{ soil property } & BD & F.C. & A.W & HC & QDP & SDP & WHP & FCP & PR & Ec & ESP & pH \\
\hline \multirow{2}{*}{ Treatment } & Sign. & $* *$ & $* * *$ & $* *$ & $* *$ & $* * *$ & $* * *$ & $* * *$ & $* *$ & $* *$ & $* * *$ & $* * *$ & $* * *$ \\
& $\mathrm{LSD}_{0.05}$ & 0.105 & 0.47 & 0.35 & 0.105 & 0.32 & 1.04 & 0.21 & 0.14 & 0.11 & 0.35 & 0.25 & 0.05 \\
\hline \multirow{2}{*}{ Rates } & $\mathrm{Sign}^{2}$ & $*$ & $* *$ & $*$ & $*$ & $* *$ & $* * *$ & $* *$ & $* *$ & $*$ & $*$ & $* *$ & $*$ \\
& $\mathrm{LSD}_{0.05}$ & 0.18 & 0.72 & 0.61 & 0.18 & 0.55 & 1.8 & 0.37 & 0.25 & 0.18 & 0.6 & 0.43 & 0.09 \\
\hline
\end{tabular}

\begin{tabular}{lcclllllllllll}
\hline \multicolumn{10}{c}{ Rank Mean of treatments addition } \\
\hline RS. & $\mathrm{b}$ & $\mathrm{b}$ & $\mathrm{c}$ & $\mathrm{b}$ & $\mathrm{c}$ & $\mathrm{b}$ & $\mathrm{c}$ & $\mathrm{a}$ & $\mathrm{c}$ & $\mathrm{b}$ & $\mathrm{b}$ & $\mathrm{b}$ \\
G. R. & $\mathrm{bc}$ & $\mathrm{c}$ & $\mathrm{b}$ & $\mathrm{b}$ & $\mathrm{b}$ & $\mathrm{c}$ & $\mathrm{b}$ & $\mathrm{d}$ & $\mathrm{b}$ & $\mathrm{c}$ & $\mathrm{c}$ & $\mathrm{c}$ \\
RS+ GR & $\mathrm{c}$ & $\mathrm{a}$ & $\mathrm{a}$ & $\mathrm{a}$ & $\mathrm{a}$ & $\mathrm{b}$ & $\mathrm{a}$ & $\mathrm{c}$ & $\mathrm{d}$ & $\mathrm{c}$ & $\mathrm{d}$ & $\mathrm{d}$ \\
Control & $\mathrm{a}$ & $\mathrm{d}$ & $\mathrm{d}$ & $\mathrm{c}$ & $\mathrm{d}$ & $\mathrm{a}$ & $\mathrm{d}$ & $\mathrm{b}$ & $\mathrm{a}$ & $\mathrm{a}$ & $\mathrm{a}$ & $\mathrm{a}$ \\
\hline
\end{tabular}

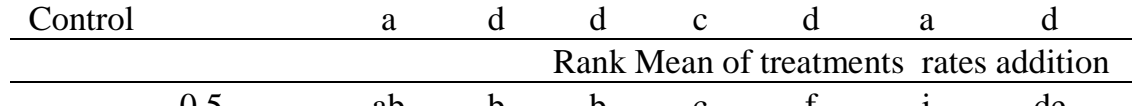

\begin{tabular}{|c|c|c|c|c|c|c|c|c|c|c|c|c|c|}
\hline \multirow{3}{*}{ RS \% } & 0.5 & $a b$ & $\mathrm{~b}$ & $\mathrm{~b}$ & $\mathrm{c}$ & $\mathrm{f}$ & $\mathrm{i}$ & de & $\mathrm{a}$ & $\mathrm{c}$ & $\mathrm{b}$ & $\mathrm{b}$ & $\mathrm{b}$ \\
\hline & 1 & $a b$ & $\mathrm{e}$ & b & $\mathrm{bc}$ & $\mathrm{f}$ & $\mathrm{c}$ & $\mathrm{e}$ & $\mathrm{cd}$ & $\mathrm{d}$ & $\mathrm{bc}$ & $\mathrm{c}$ & $\mathrm{b}$ \\
\hline & 1.5 & b & $\mathrm{c}$ & $\mathrm{c}$ & $\mathrm{b}$ & $\mathrm{e}$ & $\mathrm{e}$ & f & $\mathrm{a}$ & ef & $\mathrm{d}$ & d & $\mathrm{c}$ \\
\hline \multirow{3}{*}{$\begin{array}{c}\text { GR. } \\
\left.\text { (ton. } \text { fed }^{-1}\right)\end{array}$} & 6.8 & $a b$ & $\mathrm{f}$ & $\mathrm{b}$ & $\mathrm{c}$ & $\mathrm{d}$ & $\mathrm{d}$ & $\mathrm{cd}$ & $\mathrm{g}$ & $\mathrm{b}$ & de & $\mathrm{e}$ & $\mathrm{c}$ \\
\hline & 8.2 & $a b$ & $\mathrm{e}$ & $\mathrm{b}$ & $\mathrm{c}$ & d & $\mathrm{j}$ & $\mathrm{d}$ & de & de & $\mathrm{d}$ & f & d \\
\hline & 10.2 & $\mathrm{~b}$ & $\mathrm{e}$ & $\mathrm{b}$ & $\mathrm{a}$ & $\mathrm{d}$ & $\mathrm{f}$ & $\mathrm{C}$ & $\mathrm{f}$ & de & $\mathrm{d}$ & g & $\mathrm{d}$ \\
\hline \multirow{3}{*}{ RS+GR } & $0.5 \%+6.8$ & $\mathrm{~b}$ & $\mathrm{~d}$ & $\mathrm{~b}$ & $\mathrm{~b}$ & $\mathrm{c}$ & $\mathrm{b}$ & $\mathrm{d}$ & $\mathrm{bc}$ & $\mathrm{f}$ & $\mathrm{c}$ & $\mathrm{f}$ & de \\
\hline & $0.5 \%+8.2$ & $\mathrm{~b}$ & $\mathrm{~b}$ & $\mathrm{a}$ & $\mathrm{a}$ & $\mathrm{b}$ & $\mathrm{g}$ & $\mathrm{b}$ & ef & $\mathrm{f}$ & $\mathrm{d}$ & $\mathrm{g}$ & $\mathrm{e}$ \\
\hline & $0.5 \%+10.2$ & $\mathrm{~b}$ & $\mathrm{a}$ & $\mathrm{a}$ & $\mathrm{a}$ & $\mathrm{a}$ & $\mathrm{h}$ & $\mathrm{a}$ & $\mathrm{e}$ & $\mathrm{g}$ & $\mathrm{e}$ & h & f \\
\hline control & & $\mathrm{a}$ & $\mathrm{g}$ & d & $\mathrm{d}$ & $\mathrm{g}$ & $\mathrm{a}$ & $\mathrm{g}$ & $\mathrm{b}$ & $\mathrm{a}$ & $\mathrm{a}$ & $\mathrm{a}$ & $\mathrm{a}$ \\
\hline
\end{tabular}

\section{CONCLUSION}

Based on the aforementioned discussion, it can be concluded that the usage of any amendment (RS , Gypsum either individual or combine them in this study ) was positively significant. affect on Amelioration of the soil physical properties i.e., H.C., AW, QDP, WHP and porosity, it were increased. On the contrary, the soil chemical properties i.e., EC, $\mathrm{pH}$ and ESP, it were decreased of saline sodic soil in El-Tina Plan. The superiority of the treatment combine of RS with different rates of AGR were effected in improving soil physical and chemical properties. It was quite clears that it highly significant increased hydraulic conductivity. Also, ESP values decrease by leaching without using amendments (control) was not considerable and the soil remained sodic with highly ESP values. However, the final ESP obtained after leaching with amendments gave the highest decrease $\%$ in ESP values by using combine $0.5 \% \mathrm{RS}+$ each of 6.8 , 8.2 and 10.2 ton. fed ${ }^{-1}$ AGR). Also, the fresh yield of Spinach was higher in soils receiving with increasing rates of Agricultural gypsum amendment as compared to RS. The highest fresh Spinach yield was, obtained by treatment by combine of $0.5 \% \mathrm{RS}+$ each of $6.8,8.2$ and 10.2 ton. fed ${ }^{-1}$ AGR.

\section{REFERANCE}

Abd El Hamid, R., Azza, R. S. F. M., T.A. El- Maghraby and M. A. A. Bankry. 2011. Competency of some soil amendments used for improvement of extreme salinity of Sahl El - Tina soil J. Soil Sci and Agric. Eng. Mansoura Univ. 2 (6): 649-667.
Abdel-Fattah, M. K. and A. M. A., Merwad . 2016. Approach for reclamation and improving fertility of saline-sodic soils , Egypt. J. Soil Sci. 56 (4), 573-588.

Abdel-Fattah, K. M. 2012. Role of gypsum and compost in reclaiming saline-sodic soils. IOSR J. of Agricu. and Veterinary Sci (IOSR-JAVS). 1 (3) PP 30-38.

Abou Youssef, M. F. 2001. Use phosphogypsum fortified as a soil amendment for saline sodic soil in El-Salhiya Plain. Zagazig Journal of Agricultural Research 28: 889-911

Amezketa E.A., R. Aragues and R. Gazol. 2005. Efficiency of sulfuric acid, mined gypsum and two gypsum by-products in soil crusting prevention and sodic soil reclamation. Agron. J, 97: 983-989.

Ammari, T. G., A. B. Tahboub, H. M. Saoub, B. I. Hattar, and Y. A. Al-Zu'bi. 2008. Salt Removal Efficiency as Influenced by Phyto-Amelioration of Salt-Affected Soils, J. Food Agric. Environ., 6 (3-4), 456-460.

Antar, S. A., A. S. El-Henawy and A. A. E. Atwa. 2008. Improving some properties of heavy clay salt affected soil as a result of different subsurface tillage. J. Agric. Sci. Mansoura Univ., 33 (10), 7675- 7687.

Bello, W.B. 2012. Influence of gypsum application on wheat yield and components on saline and alkaline soils of Tigray region, Ethiopia. Greener J. of Agric. Sci., 2: $316-$ 322

Bhumbla, D.R. and I.P. Abrol. 1971. Saline and alkali in India- Their occurrence and management. FAO World Soil Resources. Rep. No. $41: 42.51$.

Chawla, K. L., and I. P. Abrol. 1982. Effect of gypsum fineness on the reclamation of sodic soils.Agricultural Water Management 5: 41-50.

Diacono M. and F. Montemurro. 2015. Effectiveness of Organic Wastes as Fertilizers and Amendments in SaltAffected Soils. Agricu., 5, 221-230. 
De-Leenheer, L. and M. De-Boodt. 1965. "Soil Physics". International Training Center for Post gradual Soil Scientist Ghent, Belgium.

El-Shanawany, E. A. 1985. Studies on the reclamation and management of salt-affected soils at Sharkia Governorate. MSc thesis, Faculty of Agriculture, Zagazig University, Egypt.

Elsharawy, M.A.O., M.M. Elbordiny and S.A. Abdel Wahed. 2008. Improvement of a salt affected soil on Bahr ElBakar area using certain industrial Byproducts: 1- Effect on physical and chemical characteristics. J. Appl. Sci. Res., 4 (7): 839-846.

FAO and IIASA. 2000. Diagnosis and improvement of saline and alkali sols, USDA Handbook No 60, U.S. Salinity Lab. Staff (1954), Washington.

Gharaibeh, M.A., N.I. Eltaif and O.F. Shunnar. 2009. Leaching and reclamation of calcareous saline sodic soil by moderately saline and moderate -SAR water using gypsum and calcium chloride. J. Plant Nutr. Soil Sci., 171, $1-7$.

Ghazy, M.A. 1994. Effect of water regime, gypsum and sewage sludge increments on the improvement and productivity of saline sodic soils. Ph.D. Thesis, Fac. of Agric., Tanta Univ., Egypt.

Ghulam, S., I. Muhammad, A. T. Mukkram, I. Yasir, S. H. Muhammad, Noor-us-Sabah, H., Kyung-Hwa, H. SangKeun, and Z. Yong-Seon. 2011. Effect of compost and gypsum application on the chemical properties and fertility status of saline-sodic soil. Korean J. Soil Sci. Fert. 44(3): 510-516.

Gupta, R. K., O. P. Sharma, and S. K. Dubey. 1988. Effect of dose and frequency of gypsum appli-cation on properties of sodic soil and on performance of rice (Oryza sativa L.) and bread wheat(Triticum aestivum L). Indian J. of Agric. Sci. 58: 449-53.

Hanay, A., Buyuksonmez, F., Kiziloglu, F.M. and M.Y. Canbolat. 2004. Reclamation of saline-sodic soils with gypsum and MSW compost. Compost Science \& Utilization 12(2): 175-179, Spring.

Hussain, N., G. Hassan, M. Arshadullah and F. Mujeeb. 2001. Evaluation of amendments for the improvement of physical properties of sodic soil. Int. J. Agri. Biol., 3 (3): 319- 322.

Junbao, Y.u., Zhichun Wang, Franz X. Meixner, Fu Yang, Huifeng and Wu, Chen. Xiaobing. 2010. Biogeochemical Characterizations and Reclamation Strategies of Saline Sodic Soil in Northeastern China Clean - Soil, Air, Water, 38 (11): 1010-1016.

Khan, R., A. Gurmani, M. Sohail and A. Hussain. 2006. Effect of gypsum application on rice yield under Wheat \& Rice System. Int. J. Agric. Biol. 8 (4): 536- 538.
Klute, A. Ed. 1986. Methods of Soil Analysis. No. 9 Part 1, Amer. Soc. Agron., Inc. Madison, Wisconsin, USA.

Lebron, I., D. L. Suarez, and T. Yoshida. 2002. Gypsum effect on the aggregate size and geometry of three sodic soils under reclamation. Soil Sci. Soc. of Amer. J. 66: 92- 98.

Mahmoud, Awatef A. 2011. Impact of some Sulphur sources on ameliorating soil characteristics, wheat yield and grain quality under newly reclaimed saline soil conditions Fayoum, J. Agric. Res. \& Dev. 25 (1): 36 - 48.

Mansour, S.F. 2002. Improvement of soil structure in some soils of Egypt.Ph.D. Thesis Fac. Of Agric. Cairo Univ., Egypt.

Manzoor, A., N. Hussain, M. Salim, and B. H. Niazi. 2001. Use of chemical amendments for reclamation of salinesodic soils. Inter. J. Agric. Bio. 3: 305-7.

Moustafa, F.A.F. 2005. Studies on reclamation of saline sodic soils. Ph.D. Thesis, Faculty of Agric. at Moshtohor, Zagazig Univ, Benha Branch, Egypt.

Reading, L.P., T. Baumgartl, K.L. Bristow, and D. A.Lockington. 2012. Hydraulic conductivity increases in a sodic clay soil in response to gypsum applications: Impacts of bulk density and cation exchange. Soil Sci. $177,165-171$.

Sabir, G. K., Izhar, ul H. Malik, A., Muhammad, J. K., Naveedullah. 2007. Effect of various levels of gypsum application on the reclamation of salt affected soil grown under rice followed by wheat crop. Sarhad J. Agric., 23, 675-680.

Saied, M. M., G. M. Elsanat, N. I. Talha, and S. M. El Barbary. 2017. On- Farm Soil Management Practices for Improving Soil Properties and Productivity of Rice and Wheat under Salt-Affected Soils at North Delta. Egypt J.Soil Sci. 57 (4): 445 - 453.

Sharma, S.D., K.G. Prasad, G.H. Khan and V.K. Sing. 1995. Gypsum and organic residue for afforestation of sodic soils. J. Tropical Forest Sci. 7,4: 580-590.

Sharma, B. R. and P. S. Minhas. 2005. Strategies for managing saline/alkali waters for sustainable agric. production in South Asia. Agric. Water Manag., 78, 136151.

Vandenelshout, S., and A. Kamphorst. 1990. Suitability of coarse-grade gypsum for sodic soilreclamation-A laboratory experiment. Soil Sci. 149: 228-34.

Wahby, W.S. 1986. Reclamation processes and their effects on some properties and crops yield in deteriorated soils of North Delta Egypt. Ph.D. Thesis, Agric.,Ain Shams Univ., Egypt.

Wong, J.W.C. and G. Ho. 1991. Effects of gypsum and sewage sludge amendment on physical properties of fine bauxite refining residue. Soil Sci. 152: 326-332. 


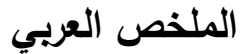

\section{تحسين بعض الخواص الطبيعية للأرض الملحية الصودية بمنطقة سهل الطينة - شمال سيناء}

\author{
هدى عبده ايليا
}

دراستها. بينما كان التأثير الاكثر فعالية على تحسين خواص a. التربة الطبيعية والكيماوية هي معاملة الخلط بين قش الأرز والجبس الزراعى. بينما كان افضل المعاملات على تحسين

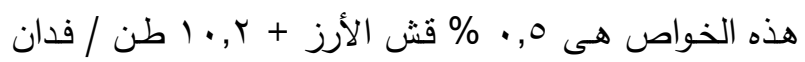

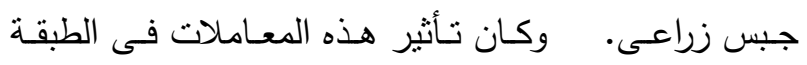

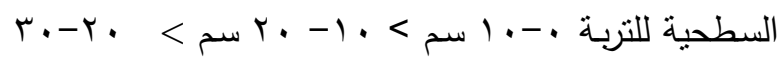

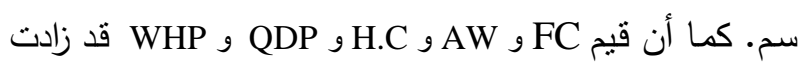

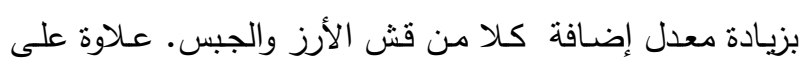

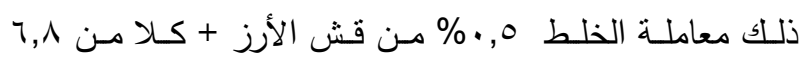

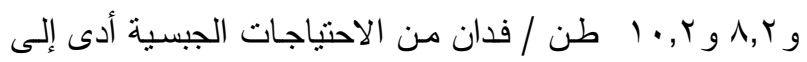

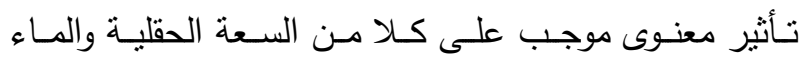

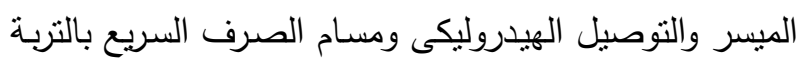
ومسام حفظ التربـة للماء مقارنـة بالتربـة المعاملة بقش الأزر أوالجبس الزراعى عند ایى معدل من الأضافة. بالإضـافة إلى الى ذلــك انخفـاض معنـوى بثــكل كبيـر فـي مقاومـة التربــة للإختراق، الكثافـة الظاهريـة ومسـام التربـة الثـعرية (الدقيقة). واثـارت النتائج ايضـاً إلى وجود إنخفاض بسيط في قيم ال

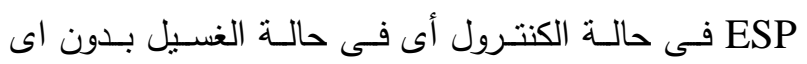

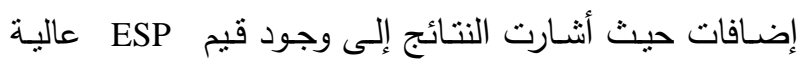
للكنترول، وعلى العكس من ذلك فى حالة الغسيل مع الإضافات

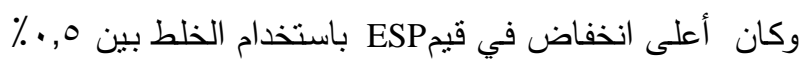

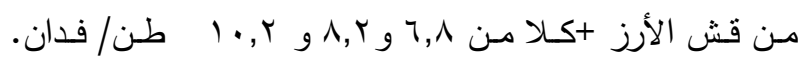

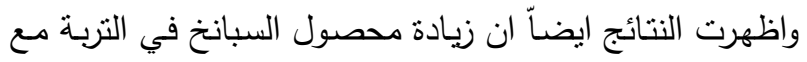

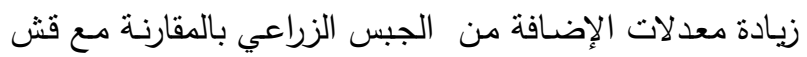

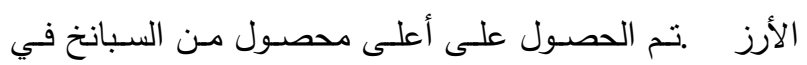

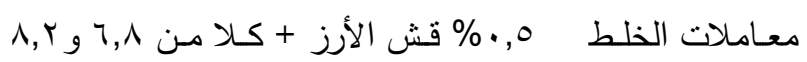
و ז, • • طن/ فدان من الجبس الزراعى.
الهدف من هذا البحث هو دراسة نأثثر كلا من قش الأرز والجبس الزراعى أومخلوطهما على تحسين الخواص الفيزيائية

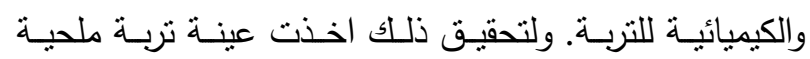
صـودية ذات قوام طميسي طيني رملى مـن الطبقـة السطحية

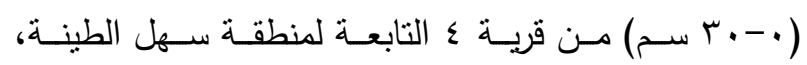
محافظة شمال سيناء - مصر • حيث أجريت تجربة صوبة هوبة.

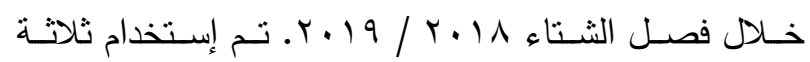
مستويات من قش الأرز وهى 0, •، 1 و 0, 1 \% وايضاً ثثلاثة

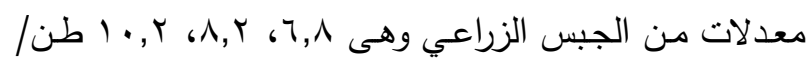

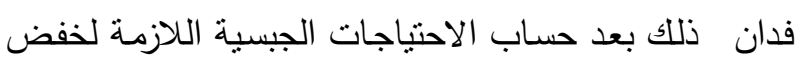

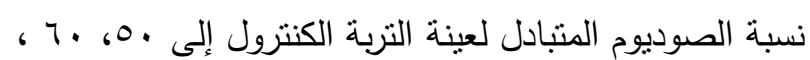
\% Vo على التوالى بالإضافة إلى ثلاتة معدلات من مخلوط

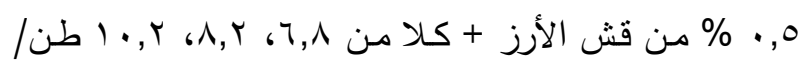
فدان جبس زراعى. تم خلط هذه المعدلات بالتربة وتحضينها

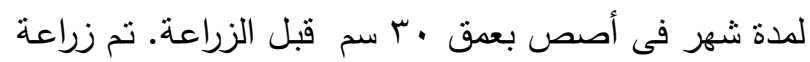

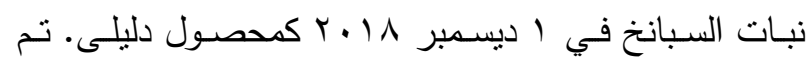
تحديـ كميـة ميـاه الري وذلك عن طريـق وزن الأصس ثم الوصول بالمحتوى الرطوبى لكل معاملة إلى السعة الحقلية +

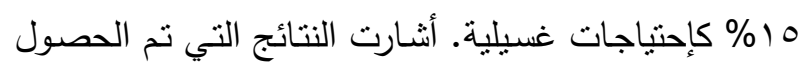
عليها إلى أن زيادة معدل الإضافة من قش الأرز (RS) أو الاحتياجات الجبسية الزراعية (AGR) أدت إلى زيادة كلا من:

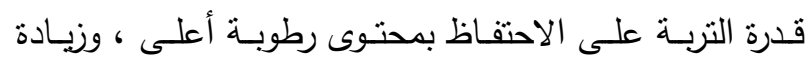

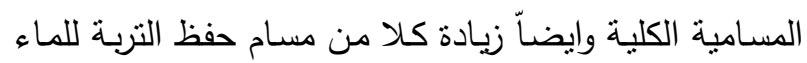

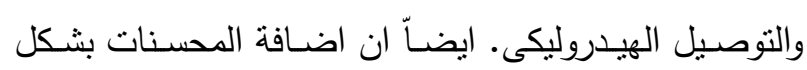
عـام ادت الـى انخفـاض كـلا مـن الكثافـة الظاهريـة للتربـة،

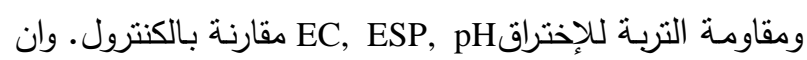

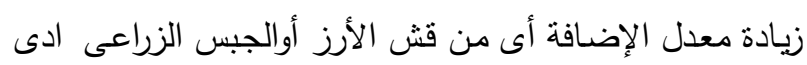

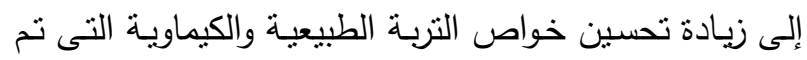

